Article

\title{
Post-Fire Resprouting in New Zealand Woody Vegetation: Implications for Restoration
}

\author{
Ana M. C. Teixeira ${ }^{1, * \mathbb{D}}$, Timothy J. Curran ${ }^{2} \mathbb{D}$, Paula E. Jameson ${ }^{3} \mathbb{D}$, Colin D. Meurk $^{4}$ and $^{-}$ \\ David A. Norton ${ }^{1}$ (D) \\ 1 School of Forestry, University of Canterbury, Christchurch 8041, New Zealand; \\ david.norton@canterbury.ac.nz \\ 2 Department of Pest-management and Conservation, Lincoln University, Lincoln 7647, New Zealand; \\ Timothy.Curran@lincoln.ac.nz \\ 3 School of Biological Sciences, University of Canterbury, Christchurch 8041, New Zealand; \\ paula.jameson@canterbury.ac.nz \\ 4 Manaaki Whenua-Landcare Research, Lincoln 7640, New Zealand; meurkc@landcareresearch.co.nz \\ * Correspondence: teixeiraamc@yahoo.com.br
}

Received: 31 January 2020; Accepted: 25 February 2020; Published: 28 February 2020

\begin{abstract}
Resprouting is an important trait that allows plants to persist after fire and is considered a key functional trait in woody plants. While resprouting is well documented in fire-prone biomes, information is scarce in non-fire-prone ecosystems, such as New Zealand (NZ) forests. Our objective was to investigate patterns of post-fire resprouting in NZ by identifying the ability of species to resprout and quantifying the resprouting rates within the local plant community. Fire occurrence is likely to increase in NZ as a consequence of climate change, and this investigation addresses an important knowledge gap needed for planning restoration actions in fire-susceptible regions. The study was conducted in two phases: (1) A detailed review of the resprouting ability of the NZ woody flora, and (2) a field study where the post-fire responses of plants were quantified. The field study was undertaken in the eastern South Island, where woody plants $(>5 \mathrm{~cm}$ diameter at $30 \mathrm{~cm}$ height) were sampled in 10 plots (10x10 m), five- and 10-months post-fire. The research synthesized the resprouting ability of 73 woody species and is the first to provide extensive quantitative data on resprouting in NZ. Most of the canopy dominant species were non-resprouters, but many smaller trees and shrubs were capable of resprouting, despite their evolution in an environment with low fire frequency. Species composition and abundance were important predictors of resprouting patterns among plots, with similar communities resulting in similar resprouting responses. Resprouting capacity provides species with a competitive advantage in the post-fire recovery. We suggest that it is possible to engineer more fire resilient restoration plantings by planting higher proportions of the resprouters identified in this study. The incorporation of resprouting as a trait in restoration plans is likely to be relevant not just in NZ, but also in other non-fire-prone regions facing increases in fire frequency.
\end{abstract}

Keywords: functional trait; fire-sensitive; non-fire-prone; persistence niche; regeneration; wildfire

\section{Introduction}

Fire is an ecological disturbance agent that plays an important role in the evolution, distribution, and abundance of woody plants worldwide [1,2]. As a result, trees and shrubs present a range of different post-fire responses and strategies to persist or re-establish in burnt areas. For instance, resprouting is an important post-fire response that allows plants to persist after fire events and is considered a key functional trait in woody plants [3]. Resprouting can be a shortcut for forest 
recovery $[3,4]$. Starting as a vigorous shoot, resprouting eliminates some risks related to seedling establishment, such as limited dispersion, seed predation, seed desiccation, and the initial, and most vulnerable, seedling stages [4]. The ability to resprout varies among species [5] and has profound effects on plant population dynamics and community assembly [6].

The capacity to recover by resprouting varies not just across species but also within species, depending on pre-fire plant conditions, fire intensity [5], and fire frequency (e.g., the resprouting capacity may be reduced under recurrent fire events). The initial production of resprouting shoots will depend on the development, protection, and resourcing of a viable bud bank [7], but other factors can influence the final recovery success, such as the vigour of the resprouts [8], the probability of predation [9], and climate conditions.

Due to its ecological importance, resprouting is well-documented in fire-prone biomes such as Mediterranean vegetation types, temperate forests in the United States and Australia, and savannas in Australia, Africa, and South America [5,6,10]. However, information on resprouting is scarce in hitherto non-fire-prone ecosystems [11]. Given that fires are becoming more prevalent globally, including in systems that have historically been considered as non-fire-prone, quantitative data collection in different vegetation types is required to develop a broader understanding of this trait and its implications [5]. New Zealand (NZ) forests are an example of a non-fire-prone vegetation type where little is known about post-fire resprouting [12], and where observations of vegetation change immediately after wildfire are rare in the literature [13]. Prior to this investigation, the only paper that directly addressed the resprouting capability of NZ native species was essentially descriptive [9] and, while it contributed as a first step to understanding resprouting in NZ, it lacked quantitative data (e.g., the proportion of plants resprouting, numbers of resprouts). Other research which focused on post-fire recovery more broadly also contributed information on resprouting in NZ species [14-17].

The forests in NZ evolved in an environment with naturally low fire frequency, with many areas having hundreds of years between fires [18,19]. This low pre-human fire frequency is mainly explained by the absence of ignition sources [12], as New Zealand has a predominantly low rate of lightning strikes [20,21] and, even when they happen, they tend to be associated with wet fronts [18] resulting in small scale fires [19]. As a consequence of its evolution with limited exposure to fire, the indigenous flora is poorly adapted to fire $[12,19,22]$. When Polynesians arrived in NZ in the mid-13th century, fires were introduced to the landscape at a much greater frequency, resulting in rapid and substantial forest loss $[18,23]$. Forests were locally burned to clear land for agriculture, facilitate cross-country travel, and to encourage the growth of bracken (Pteridium esculentum), which was used as a food source [24-26]. Nevertheless, the Polynesian fires led to extensive forest losses because of limited ability to control them once started and so in most cases large-scale deforestation was likely accidental [19,26]. Planned European settlements occurred from around 1840 [18], and by 1900, extensive areas of forest in lowland and eastern areas of NZ were removed by felling or burning to extract timber and create pasture [27]. The impact of European settlement was much more severe than the Polynesian occupation period due to the further reduction in forest cover and the introduction of exotic plants and animals leading to the extinction of many native species [28,29].

In NZ ecosystems, forest burning favors the establishment of early successional native species, such as Pteridium esculentum, Kunzea spp., and Leptospermum scoparium, and facilitates the invasion of woody exotic species, such as Ulex europaeus, Cytisus scoparius and Hakea spp. [30]. The colonization of these species in early post-fire successional states results in the development of a vegetation type more flammable and fire-prone than the original pre-fire forest [12,31]. As a consequence, this dynamic has the potential to create a positive feedback between fire and vegetation succession [32]. As common invasive species are often pyrophyllic and well adapted to fire, while the native flora generally is not [19], these invasions potentially alter the successional trajectories, and may even arrest the successional process [31], creating novel fire-prone ecosystems dominated by woody exotic species. When this threshold is crossed, restoration efforts may be crucial to enhance the re-establishment of the native 
forest, including reintroduction of native species, control of exotic species, and management actions aiming to reduce local fire frequency and intensity.

Fire occurrence in NZ has been increasing in the last few decades. The most recent and detailed wildfire analysis shows that the number of wildfires increased from about 1200 fires per year in the early 1990s, to over 4000 fires per year in 2006/2007 [33]. In addition, climate change models predict that fire risk is likely to increase further in $\mathrm{NZ}$ as a consequence of higher temperatures, reduced rainfall, and stronger winds [34,35].

Considering this trend of increasing fire frequency, understanding how plants respond to fire and whether a species will resprout or not is of paramount importance for planning forest restoration and conservation. Our investigation into post-fire vegetation responses in NZ forests addressed three main questions. Firstly, can woody species that have evolved in a land with very low frequency of fire events resprout following a fire? Secondly, do resprouting rates vary between species? And, finally, how do species composition and abundance influence resprouting rates within the local plant community? Ultimately, by answering these questions, this study provides insights to guide the restoration and conservation of forests located in regions of NZ that are currently under increasing fire pressure. This contribution is likely to be relevant not only in NZ but also in other countries and biomes that have not historically experienced frequent fire, but which are now facing increasing fire occurrence because of the combined effects of human presence and climate change. This study was undertaken after a large wildfire in late summer 2017 on the Port Hills, Christchurch City, NZ, which burnt through a mosaic of native second growth regenerating forest, exotic scrub and grassland.

\section{Materials and Methods}

The study was conducted in two phases: the first consisted of a detailed literature review in order to identify what is known about the resprouting capacity of the NZ woody flora, and the second comprised a field-based study where post-fire responses of plants were quantified, monitored, and analysed.

\subsection{Resprouting Review}

Aiming to understand if the NZ woody flora, which evolved in an environment with low fire occurrence, is able to resprout after fire, we conducted an extensive survey of the literature referring to the resprouting ability of NZ species. We searched the Scopus database for international publications, and the query included fire and sprout* in any part of the text, and "New Zealand" in the title, abstract, or key-words (ALL (sprout* AND fire) AND TITLE-ABS-KEY ("New Zealand")). For national publications, the databases of New Zealand Journal of Botany (NZJB) and New Zealand Journal of Ecology (NZJE) were thoroughly searched. The query used in the NZJB included sprout AND fire, and resprout AND fire in any part of the text. And the NZJE was searched using fire in the title, abstract, and keywords, and searching in each article for sprout or resprout. The queries were adapted to the peculiarities of each database searched. Based on the literature, a list of NZ woody species and their binary resprouting response (yes or no) was developed. The position of resprouting buds, quantitative information (e.g., resprouting percentage), and relevant comments were included when available. The botanical nomenclature followed the New Zealand Plant Conservation Network (http://www.nzpcn.org.nz/, accessed on 10 January 2020).

\subsection{Field Study Site}

The field study was undertaken on the Port Hills $\left(43^{\circ} 37^{\prime} \mathrm{S}, 172^{\circ} 37^{\prime}\right)$, on the east coast of NZ's South Island, near the city of Christchurch (Figure 1). The study area has a rugged topography and rises from the sea level to $573 \mathrm{~m}$. Soils are mainly derived from basaltic bedrock and loess. The average annual rainfall varies from 600 to $800 \mathrm{~mm}$, with periodic droughts during the summer. Originally, the area was covered mainly with podocarp-broadleaved forest but practically all the forest cover was removed by felling or burning by the European settlers to create pasture and extract timber, with 
the old growth forest reduced to tiny fragments [27]. During the last few decades, much effort has been made to preserve and restore the forests in the region, and currently there is a trend towards an increasing area covered by native second growth regenerating forest. A detailed characterization of the Port Hills region is presented by Wilson [27-29,36].

In February 2017, the region was burnt with two adjacent wildfires affecting about 1660 ha [35] (Figure 1). The burnt area was comprised of a complex mosaic of vegetation including pine plantations (approximately 530 ha), exotic shrubland dominated mainly by Ulex europaeus and Cytisus scoparius (475 ha), pastureland (315 ha), and native vegetation in different stages of regeneration back to forest (155 ha). Our study was focused on these burnt patches of native regenerating forest (Appendix B-Figure A1).

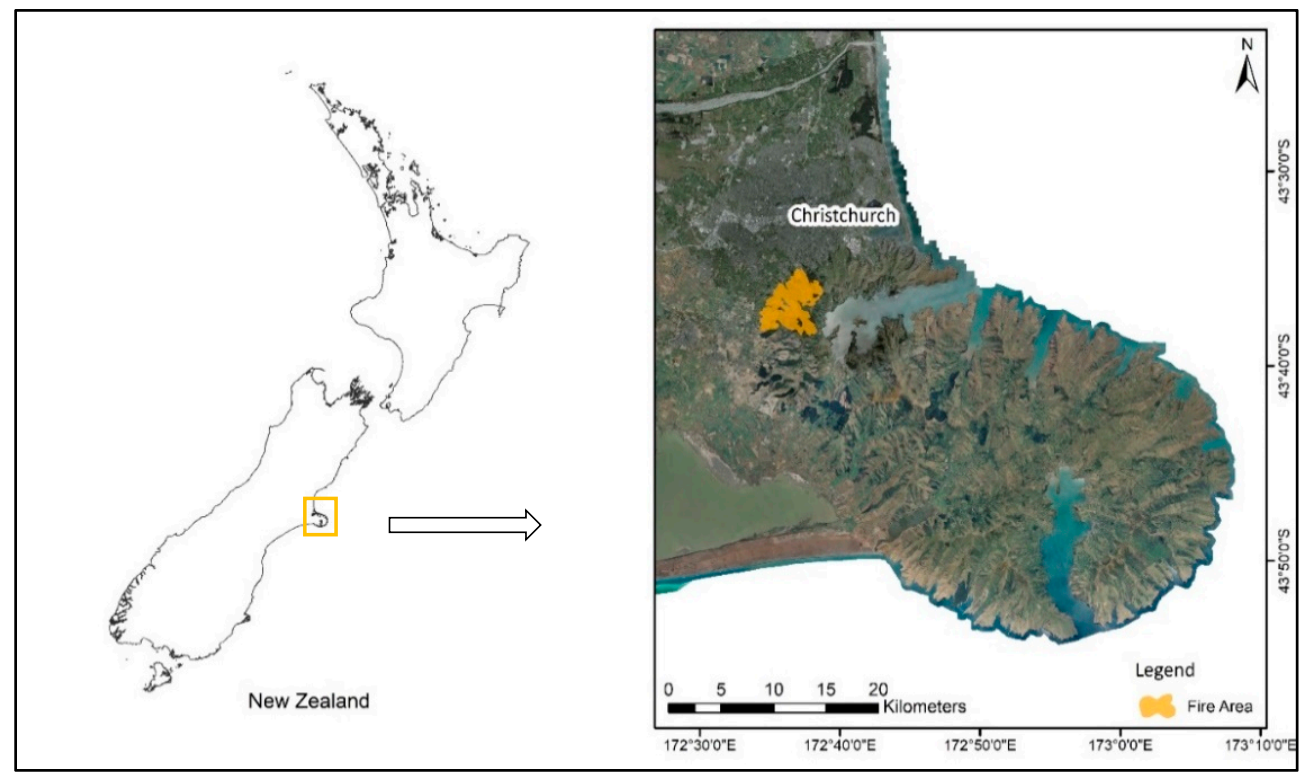

Figure 1. Location of the area affected by the wildfire (yellow polygon) on the Port Hills, near the city of Christchurch, New Zealand.

\subsection{Sampling and Measurements}

The burnt patches of native second-growth forest were sampled in ten $10 \times 10 \mathrm{~m}$ plots (Appendix B-Figure A1). The sample design was planned using both pre- and post-fire orthophotography and field observations of the study area. The pre-fire orthophotography was taken in the flying season of 2015-2016 and the post-fire was taken in March 2017. The imagery was provided by Land Information New Zealand and Environment Canterbury, respectively, and was supplied using a New Zealand Transverse Mercator 2000 (NZTM 2000) with a $30 \mathrm{~cm}$ pixel resolution (0.3 m GSD), 3-band (RGB). The orthophotography was used to identify the main burnt vegetation types. The burnt areas that classified as native second-growth forest in the pre-fire orthophotography were selected for study. Potential plot locations were identified, taking into account accessibility, the density of burnt trees (forest rather than scattered trees), and an effort to obtain a representative spatial coverage of the total burnt area. The location of the potential plots was then stratified in two main strata (1) kanuka dominant canopy (5 hectares burnt), and (2) mixed angiosperm canopy (137 ha burnt). The identification of these strata was based on the pre-fire orthophotography, more specifically on the tone, which is one of the main characteristics used to identify and classify imagery features. In this case, the foliage of the kanuka dominant canopy reflected less light than the mixed angiosperm canopy, with kanuka crowns darker and distinct in the landscape. After stratification, plots were located randomly on the map, and the geographic coordinates of each plot were used to locate plots in the field. The randomization was restricted to $100 \mathrm{~m}$ from tracks to facilitate access and re-measurement. 
The first field sampling was undertaken five months after the fire. All the burnt woody plants $\geq 5 \mathrm{~cm}$ diameter, as measured at $30 \mathrm{~cm}$ above ground level, were counted and identified. Any sign of resprouting was recorded for each individual. The stems were tagged in order to facilitate ongoing monitoring, and the resprouts were counted and classified according to their position on the plant-basal or epicormic. Growth form, crown architecture, and bark characteristics were used to identify the species, as there were no data on the vegetation present in the plots prior to the fire event.

The second sampling was undertaken 10 months after the fire event. New signs of resprouting were recorded and, in order to monitor the vigour and survival of resprouts, the plants tagged in the first sampling were checked, the number of resprouts were counted. Any signs of resprouts wilting or being browsed were recorded. Additional sampling was undertaken beyond the sampling plots, in random walks, in an effort to increase the number of individuals sampled per species, with the aim of having at least nine individuals of each species sampled.

\subsection{Data Analysis}

The species were classified according to the percentage of individuals capable of resprouting, obtained from the number of resprouting individuals and the total number of individuals per species. When the resprouting rate was $\geq 70 \%$, the species were considered as strong-resprouters; between $30 \%$ and $70 \%$, intermediate-resprouters; and $\leq 30 \%$, weak- and non-resprouters, as suggested in [37]. In order to determine if the proportions of resprouting differed across species, a chi-squared test was conducted for the most abundant species $(N>12)$.

The total resprouting rate and type (basal and epicormic) were calculated for each plot and, based on these results, the plots were grouped according to the resprouting patterns identified. Data originating from the extra sampling (i.e., beyond the plots) were not included in this analysis. Non-metric multidimensional scaling (NMDS) $[38,39]$ was performed to ordinate the plots in a reduced number of dimensions and to support the visualisation of the plots' similarities in terms of overall species composition. For this, we used a matrix of species abundance data for the pre-fire vegetation, although it was collected after the fire and species were identified based on plant growth form, crown architecture and bark characteristics. The data included all the individuals identified in the plot independent of their resprouting capacity (resprouters and non-resprouters were included). We used the function metaMDS from the package "vegan 2.4-2" [40] in the R programme (version 3.6.0), applied Wisconsin double standardization to the data and adopted the Bray Curtis similarity index. The minimum number of random starts in search of a stable solution was 50 and the maximum was 500, and the number of iterations stopped after reaching this minimum number and finding two convergent solutions. The results were scaled by using the default options of metaMDS. The appropriate number of dimensions (axes) was assessed by plotting final stress values against the number of dimensions on a scree plot using the function dimcheckMDS from the package "goeveg". To examine the influence of species composition and abundance on the post-fire resprouting responses, we used a permutational multivariate analysis of variance (PERMANOVA). The PERMANOVA was conducted using the adonis function from the package "vegan 2.4-2" [41] and was based on the same species abundance matrix used in the NMDS. This analysis was used to compare the plots' species abundance against the resprouting patterns. We used the Bray Curtis dissimilarity index and 999 permutations to do this.

\section{Results}

\subsection{Resprouting Review}

The review of resprouting in NZ woody species resulted in observations for 73 species, which are summarized and presented in Appendix A. Most of the observations were qualitative and classified the species resprouting capacity in a binary system, while quantitative data (with $n \geq 4$ ) was available for just 23 species, representing $28 \%$ of the data set. The field-based phase of our research provided quantitative information on 15 species, from which five species had no previous information and two 
species had just qualitative information. The other quantitative data presented originated from 'grey' literature and included two Master theses and an undergraduate report.

Most of the species that usually form the tallest tier of the conifer-broadleaved forests, one of the two main forest types in NZ, were classified as non-resprouters. These species included the conifers Dacrycarpus dacrydioides (kahikatea), Dacrydium cupressinum (rimu), Podocarpus spp., and Prumnopitys taxifolia (matai). An exception was Agathis australis (kauri), which was considered capable of resprouting, although also considered sensitive to fire. Some tall broadleaved angiosperms that can form a tier beneath the conifers, or the main canopy when conifers are absent or sparse, were classified as non-resprouters, such as Metrosideros spp., but others were classified as resprouters (e.g., Beilschmiedia spp. and Weinmannia racemosa). The canopy species of the beech (Nothofagaceae) forests, the other main forest type in NZ, were all classified as non-resprouters. These species were also considered to be poor colonizers after fire, and very sensitive to burning. While most of the canopy dominant species of the two main NZ forest types were non-resprouters, many medium and small trees and shrubs were considered capable of resprouting, despite their history of little exposure to fire events (e.g., Coprosma spp. and Melicytus spp.).

\subsection{Field Study—Species' Responses}

A total of 453 woody plants were assessed, 373 in the plots and 80 around the plots (extra samples). The total resprouting rate rose from $17 \%$, five months after the fire, to $38 \%$ ten months after. From the 24 species identified, 20 were native and four exotic. The exotic species represented $15 \%$ of the total number of woody plants. The 15 most common species $(n \geq 9)$ represented $92 \%$ of the sample, and their resprout proportions were extremely variable. Considering the resprouting ability of these species, three species were classified as strong resprouters, four as intermediate, and eight as weak or non-resprouters (Table 1).

Table 1. Classification of resprouting ability for the most abundant species $(n \geq 9)$, along with their flammability category [22], and dispersal mode [40]. The proportion of individuals resprouting varied across different native species $(\chi=196.2$; d.f. $=9 ; p<0.001)$. The majority of native species are evergreen, except Fuchsia and Plagianthus. ${ }^{*}$ Exotic species.

\begin{tabular}{|c|c|c|c|c|c|c|}
\hline Species & $\mathbf{N}$ & Origin & Resprout \% & $\begin{array}{l}\text { Resprout } \\
\text { Ability }\end{array}$ & $\begin{array}{l}\text { Flamm. } \\
\text { Category }\end{array}$ & Dispersal \\
\hline Cordyline australis & 20 & Native & 100 & Strong & Low/Mod & bird \\
\hline Fuchsia excorticata & 9 & Native & 100 & Strong & Low & bird \\
\hline Sambucus nigra * & 15 & Exotic & 87 & Strong & NA & bird \\
\hline Melicytus ramiflorus & 126 & Native & 69 & Intermediate & Low & bird \\
\hline Coprosma robusta/lucida & 33 & Native & 64 & Intermediate & Low/Mod & bird \\
\hline Griselinia littoralis & 11 & Native & 55 & Intermediate & Low & bird \\
\hline Ulex europaeus * & 47 & Exotic & 13 & Weak & Very high & ballistic \\
\hline Plagianthus regius & 11 & Native & 9 & Weak & Very low & gravity/wind \\
\hline Pseudopanax arboreus & 43 & Native & 5 & Weak & Low & bird \\
\hline $\begin{array}{c}\text { Pittosporum } \\
\text { tenuifolium/eugenioides }\end{array}$ & 35 & Native & 3 & Weak & Low/Mod & bird \\
\hline Kunzea robusta & 39 & Native & 0 & None & High & wind \\
\hline Olearia avicenniifolia & 12 & Native & 0 & None & NA & wind \\
\hline Veronica salicifolia & 14 & Native & 0 & None & NA & wind \\
\hline
\end{tabular}

Note: Coprosma robusta and C. Lucida, and Pittosporum tenuifolium and P. eugenioides were analysed together. These congeneric species pairs presented very similar bark and crown architecture, and it was not possible to confidently separate these species when they did not resprout. In general, Coprosma robusta seemed to be more abundant than $C$. lucida in the sampled region.

Melicytus ramiflorus, classified as an intermediate resprouter, was the most abundant species, representing $28 \%$ of the total number of plants. The majority (56\%) of the burnt trees were top killed 
and resprouted from the base. Epicormic resprouts were observed in $21 \%$ of trees, and a combination of epicormic and basal resprouts in a further $23 \%$. The trees that presented epicormic or a combination of epicormic and basal resprouts, often resprouted vigorously, producing more than 10 resprouts per plant. In the case of the top-killed trees, the resprouts were less vigorous, with the majority presenting fewer than five resprouts.

Low intensity herbivory was observed on several individuals of $M$. ramiflorus (11) and one F. excorticata. Based on the height of the predated leaves and field observations, the former was likely to have been predated by goats and the latter by hares. Dry or withered resprouts were observed on a few trees of M. ramiflorus (3), P. eugenioides (1), F. excorticata (1), G. australis (1), and U. europaeus (3).

\subsection{Field Study-Community Response}

The total resprouting rate in the plots varied from $7 \%$ to $74 \%$, and the proportion of basal and epicormic resprouts was also variable. Based on this variability, different resprouting patterns were identified, and three groups of plots could be distinguished (Figure 2). The first group (G1) comprised the plots where resprouting rates were less than $10 \%$. The second (G2) included plots with intermediate resprouting rates, from $10 \%$ to $40 \%$, and the resprouting type was essentially basal. The third group (G3) was composed of plots with higher total resprouting rates, greater than $40 \%$, and the resprouting types included both epicormic and basal resprouts.

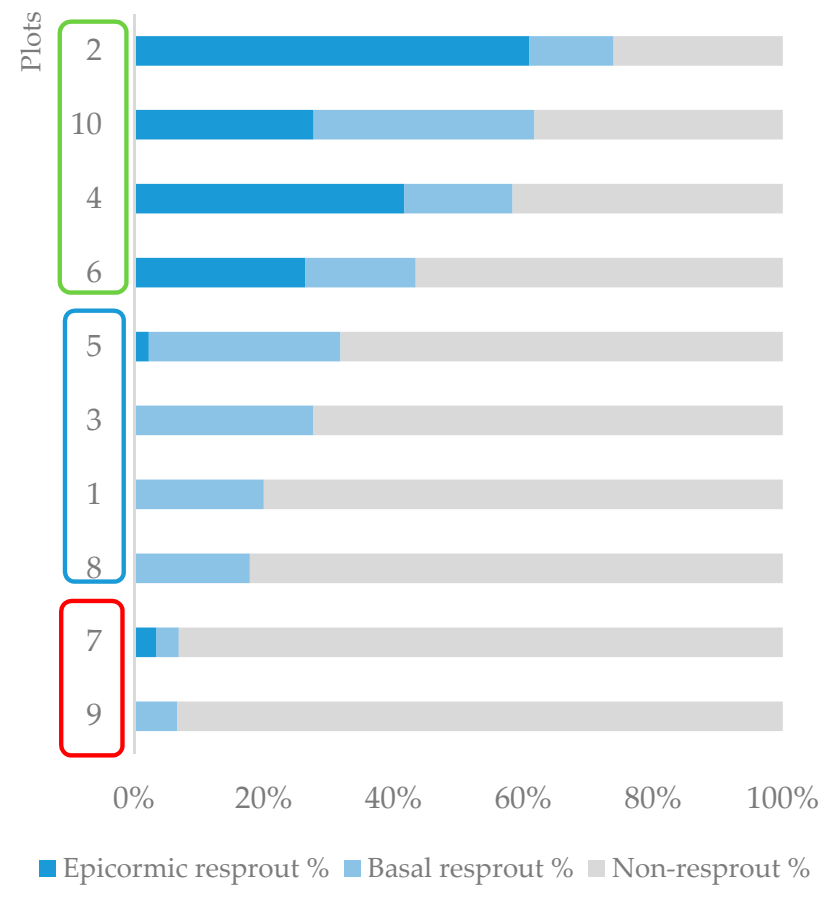

Figure 2. Total resprouting rate and proportion of resprouting type per plot. The different resprouting patterns identified resulted in three groups of plots: G1 (red), G2 (blue), and G3 (green).

The results of the NMDS ordination (Figure 3) and the PERMANOVA indicated that species composition and abundance were important predictors of resprouting patterns among plots, with similar communities resulting in similar resprouting patterns. The two-dimensional NMNDS ordination explained $95 \%$ of the species abundance similarity matrix (final stress $=0.09$ ). Solutions with more dimensions only minimally reduced stress. The PERMANOVA showed that the pre-fire community abundance and composition significantly influenced the post-fire resprouting patterns identified in the plots $\left(p<0.01, \mathrm{R}^{2}=0.58\right)$. Among the plots with greater resprouting rates (G3), Melicytus ramiflorus was the most abundant species, representing $81 \%$ of the total number of individuals in plot $10\left(38 \mathrm{ind} / 100 \mathrm{~m}^{2}\right), 65 \%$ in plot $2\left(15 \mathrm{ind} / 100 \mathrm{~m}^{2}\right), 40 \%$ in plot $6\left(21 \mathrm{ind} / 100 \mathrm{~m}^{2}\right)$, and $33 \%$ in plot 4 
(12 ind $\left./ 100 \mathrm{~m}^{2}\right)$. In contrast, the plots with the lowest resprouting rates (G1) were strongly dominated by Kunzea robusta, with $86 \%$ of the total number of individuals in plot 7 and $93 \%$ in plot 9 .

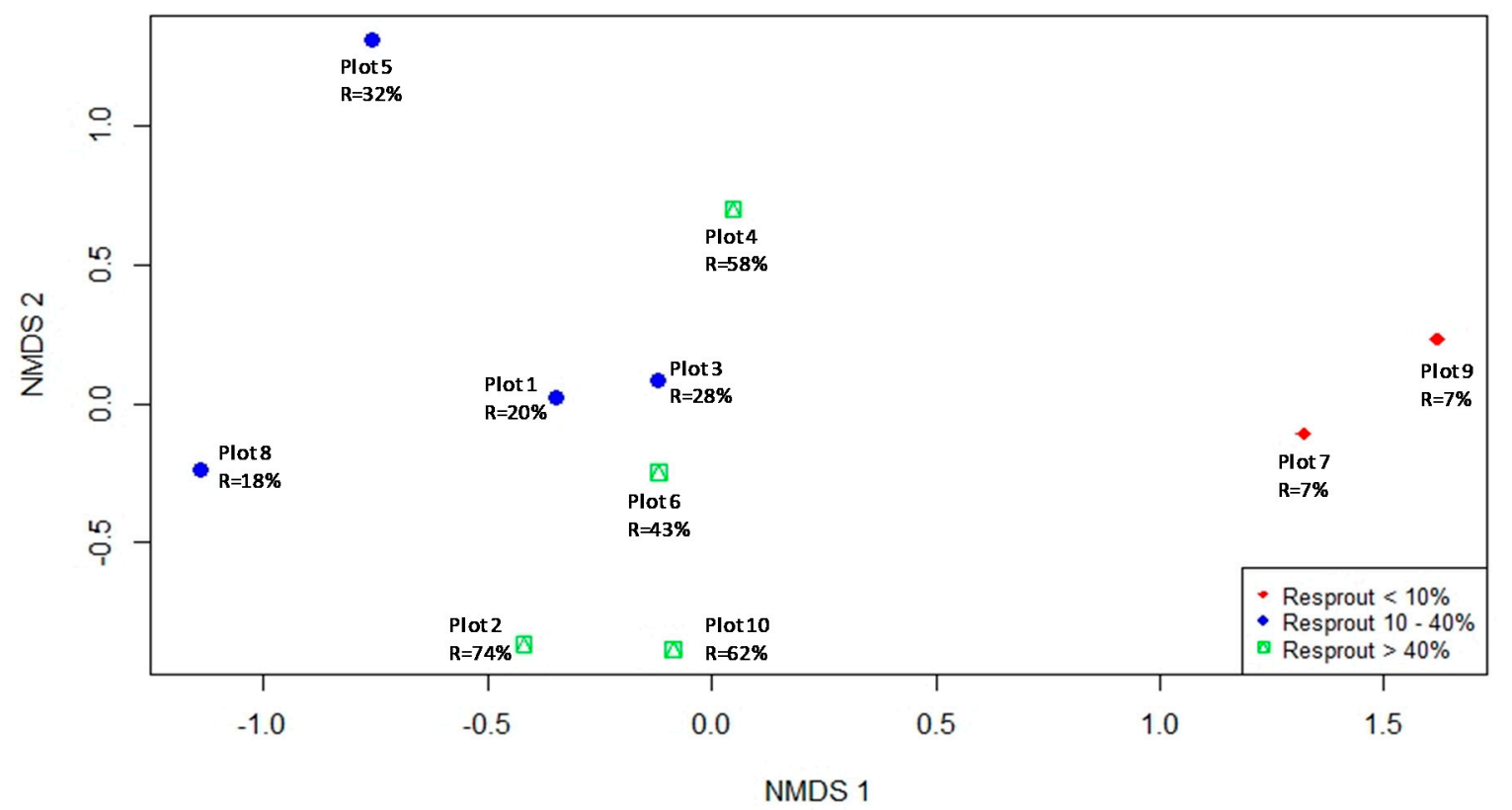

Figure 3. Results of the two-dimensional non-metric multidimensional scaling (NMDS). Resprouting groups are represented by colours: G1 (red), G2 (blue), G3 (green), and resprouting percentages are shown under each plot label.

\section{Discussion}

\subsection{Resprouting Review}

The scarcity of quantitative resprouting information identified in our research reflects a global trend, as many studies worldwide report just a binary resprouting response and far fewer report quantitative data [5]. However, understanding resprouting goes beyond binary responses [6], as resprouting represents a spectrum of probability between zero and one, and collecting quantitative data is fundamental for better understanding of this trait [5].

Most of the dominant canopy tree species in the NZ conifer-broadleaved forests are conifers incapable of resprouting. This absence of resprouting is not uncommon among other gymnosperms worldwide [5]. In addition, in comparison to angiosperms, epicormic resprouting is limited to just a few gymnosperm species, probably due to their lack of axillary meristems and hydraulic limitations [7].

In contrast, the dominant species of the NZ beech forests, which are also not capable of resprouting, belong to a family of plants, the Nothofagaceae, that present great variability globally concerning resprouting responses, with some of them being successful post-fire resprouters in other regions of the world. For example, in the Valdivian rain forests in Southern Chile, Nothofagus obliqua and N. alpina are dominant canopy tree species, and both resprout after being burnt [42]. In Tasmania, Australia, N. cunninghamii is also capable of resprouting after fire events [43].

Despite the absence of resprouting capability in most of NZ's canopy dominant species, many smaller trees are able to resprout after burning. Resprouting can be related to ancient floras $[11,44]$ and is also a common response to many other disturbance types, including wind, herbivory, landslides, hurricanes, and floods. Thus, it is possible that the resprouting ability of native species in NZ's non-fire-prone forests has its origins in ancestral lineages or had been shaped by evolutionary forces other than fire [45]. Independent of their origin, their resprouting capacity will provide these species with a competitive advantage in post-fire recovery. 


\subsection{Species Response}

The majority of the native species sampled in the field study appeared incapable of resprouting or resprouted at very reduced rates. This result was expected and can be explained by the species' evolution in an environment with a naturally low fire frequency [12,19]. Some of the species classified as nonor weak-resprouters, such as Pseudopanax arboreus, Kunzea robusta, Pittosporum tenuifolium/eugenioides, Veronica salicifolia, Olearia avicenniifolia, and Plagianthus regius, were abundant in the pre-fire vegetation and their lack of resprouting has strong implications for the post-fire vegetation recovery process.

Kunzea robusta, V. salicifolia, O. avicenniifolia, and P. regius produce small wind-dispersed seeds that are not able to survive fire and, due to their inability to resprout, their recovery after a fire will rely on dispersal from unburnt patches in the region. Kunzea robusta was incapable of resprouting even when not severely burnt, and similar results were also observed in other research carried out in NZ with this species (e.g., in Hinewai reserve and in Marlborough [15,46]). The resprouting capacity of $V$. salicifolia, O. avicenniifolia, and P. regius was assessed for the first time in the present study. Further observation in different study sites is required to confirm their inability to resprout, as resprouting response can vary depending on many factors, including fire intensity [5], plant size, post-fire environmental conditions, and site productivity [8].

The resprouting rates registered on the Port Hills for Pseudopanax arboreus $(5 \%, n=43)$ and Pittosporum tenuifolium/eugenioides $(3 \%, n=35)$ were very low compared to the results of a previous study carried out in Hinewai Reserve [47]. At Hinewai, $100 \%$ of the P. arboreus trees sampled $(n=7)$ resprouted, as did $87.5 \%$ of the P. eugenioides $(n=16)$. The contrasting resprouting responses recorded in these two relatively close locations (both study sites are situated in the same ecological region-Banks Peninsula), might be attributed to different burn intensities, and moisture regime. The Hinewai fire occurred during winter and was a natural fire ignited by a lightning strike, and it is likely that it was less severe mainly because of the moister climate conditions typical in winter in this region, although conditions were unusually dry when the fire occurred. In contrast, the Port Hills fire occurred in summer and involved two distinct fires that merged into a large, intense fire [35].

Consequently, we suggest that the resprout response of P. arboreus and P. tenuifolium/engenioides may be dependent on fire intensity, with more intense fires constraining the resprouting capability. While there is no research demonstrating the relation between fire intensity and resprout capacity in NZ, in general resprouting proportions are considered a result of a species' intrinsic resprouting ability combined with the disturbance intensity, and a decline in resprouting capacity is expected as a consequence of an increase in disturbance intensity [5]. For instance, after intense wildfire, even species native to fire-prone ecosystems and regarded as resprouters may fail to resprout or will resprout at very low rates [47].

The native species C. australis and F. excorticata (Appendix B, Figure A2) showed the highest resprouting rates and were considered strong resprouters. C. australis is well known for its resprouting ability [9], and resprouted even when severely burnt. Seedlings of C. australis were also observed resprouting in a burnt restoration planting site near the study plots (personal observation, AMCT), demonstrating the capacity of this species to recover after fire events. The strong resprouting performance of $F$. excorticata has also been reported previously $[9,19,46]$.

Intermediate resprouting rates were observed in C. robusta/lucida (Appendix B, Figure A3), G. littoralis (Appendix B, Figure A4) and M. ramiflorus (Appendix B, Figure A5). While no specific information about $C$. robusta or C. lucida is available in the literature, the resprout ability of species in the genus Coprosma is well documented, with most species studied capable of resprouting (Appendix A). G. littoralis and M. ramiflorus also resprouted after the fire in Hinewai reserve [46], but the resprouting proportions there were greater than in the present study. The reasons for this difference are probably the same as discussed for P. arboreus and P. tenuifolium/eugenioides above.

Although the NZ vegetation is not fire adapted, some native species were capable of resprouting following fire. From the most abundant species sampled, $45 \%$ of the native species were intermediateor strong-resprouters (see Table 1). Similarly, in the Amazonian rainforest, where the native flora also 
evolved in the absence of fire, a modest proportion of the native plants was capable of resprouting after wildfires [48]. The results of a study conducted in five patches of Amazonian forest showed that 59\% of the species were capable of resprouting, presenting great variation rates among species, and the total number of individuals resprouting was approximately $40 \%$ [48], which is very similar to the results of the present study $(38 \%)$.

Even though some of the native species in non-fire-prone forests can resprout after wildfire, the percentage of resprouting species is much smaller than in fire-prone forests. For example, in Australian fire-prone forests, the percentage of woody species capable of resprouting can reach $90 \%$ [49], and in a South-western China forest $100 \%$ of the trees and $93 \%$ shrubs resprouted within six months after fire [50]. Having a smaller percentage of species capable of resprouting is one of the reasons why non-fire-prone forests have their biodiversity more negatively impacted by fire events than fire-prone forests.

The exotic species represented an important component of the total number of woody species sampled, with Ulex europaeus (gorse) being the most abundant exotic species. In its natural distribution in Western Europe, U. europaeus is a strong resprouter and the germination of its seeds is also stimulated by fire, which makes this species a very successful coloniser after fire events [51]. On the Port Hills, perhaps surprisingly, U. europaeus seldom resprouted, but its seeds germinated vigorously, producing carpets of seedlings (Appendix B, Figures A5 and A6). Potentially, below-ground or basal resprouts were hidden amongst the abundant seedlings, which may have led to an underestimation of the resprouting rate. Therefore, further investigation may be required to verify if the low resprouting rate is actually a pattern for this species in NZ, or if it was a consequence of underestimation.

In the Port Hills landscape, exotic woody species that benefit from fire events are common and widespread in the landscape. Considering that these invasive species are fire adapted and capable of recruiting seedlings with great efficiency (e.g., U. europaeus and C. scoparius), the native flora recovery process faces strong competition. In this competitive environment, resprouting capacity is a vital feature for the native species. Resprouting is a mechanism that allows plants to persist after disturbances and confers advantages in the recovery process, as resprouts often grow faster than seedlings [3] and, therefore, are more competitive, especially in the initial successional stages. In general, resprouters can form larger and taller crowns faster than seedlings because they have larger carbohydrate reserves [52] and larger root systems that usually go deeper into the soil and have more surface area for the absorption of water and nutrients [53].

On the other hand, the recovery of non-resprouters will rely on dispersed seeds from neighboring populations or surviving individuals, and if this dispersal is not efficient and there is strong competition, the recovery of these species will be very slow or they may even face local extinction [10]. Thus, from a conservation and restoration perspective, resprouters will generally demand less active management to re-establish than non-resprouters [3].

\subsection{Community Response}

The influence of species composition and abundance on the resprouting pattern among the plots can be explained at two different levels: firstly, a direct influence, which is the result of the intrinsic resprout capacity of each species; then, indirectly, with species composition and abundance influencing the local fuel flammability, and therefore the fire intensity. Variation in local fire intensity resulting from fuels with different flammability has the potential to influence post-fire responses [54] and, in general, as fire intensity increases, resprouting capacity decreases [5].

Among the first group of plots (G1, resprouting rates $<10 \%)$, K. robusta was the dominant species. This pioneer species is highly flammable [23], and often occurs in essentially pure stands [55,56]. The strong dominance of this non-resprouting species added to its high flammability explains the very low resprouting rates in these plots.

On the other hand, $M$. ramiflorus was the dominant species in the third group of plots (G3, resprouting rates $>40 \%$ ). This species presented relatively high resprouting capability, which directly 
influenced the plots' total resprouting rate. In addition, it is likely that the low flammability of $M$. ramiflorus [23] led to less intense fire at a local scale. When the leaf litter flammability is reduced, a reduction in fire intensity and an increase in the probability of a tree resprouting is expected $[54,57,58]$. Indeed, the high epicormic resprouting rates registered in these plots also suggest that the fire was less intense [59].

Important mechanisms that explain how the different flammability components change when mixtures of species are burnt together were revealed in laboratory experiments conducted in different locations and including species from different ecosystems. As a general rule, the more flammable species of a pair drives the net flammability at the shoot level and at the litter level, and this effect is non-additive [60-62]. A trial conducted with NZ native and exotic species demonstrated that the more flammable species increases the ignition speed and the fire temperature, while the less flammable may contribute to reduce the burning time [63]. These mechanisms may explain the flammability influence of K. robusta in G1 plots and of M. ramiflorus in G3 plots.

The second group of plots (G2, resprouting rates $10 \%-40 \%)$, showed more variation in species composition and abundance when compared with the other groups. In contrast to the plots in G1 and G3, the G2 plots did not share a common dominant species and interpretations on how flammability of the species influenced the resprouting rates in this case are more complex and unclear.

The high flammability of $U$. europaeus probably influenced the resprouting responses of the native species, as $U$. europaeus occurred in the majority of the plots studied (6/10 plots) and was also widespread across the burnt landscape. Due to the high flammability of its leaves [22] and the retention of significant amounts of dead flammable material, $U$. europaeus can strongly influence fire temperature [63], increasing the fire intensity over what would be expected if the generally less-flammable NZ native vegetation was burning in isolation [62]. By increasing the fire intensity, the likelihood of the native plants resprouting was probably reduced. However, it was not possible to interpret the direct effect of the high flammability of $U$. europaeus on the resprouting rate in each plot. The complexity of the composition and structure of the plots, for example, U. europaeus, combined with different mixtures of native species in different proportions, emphasizes the challenge of understanding how several species may influence fuel flammability, and how this affects the resprouting rates within a community.

Despite being unable to disentangle the direct effect of $U$. europaues on resprouting rates within plots, it is broadly recognised that highly flammable invasive plants have the potential to alter fire regimes and the response of plants to fire occurrence. By changing fuel conditions and increasing fire intensity, the invasive species thrive under the new fire conditions created by them $[64,65]$. Probably, when $U$. europaeus replaces areas previously dominated by $\mathrm{NZ}$ forests, it has the potential to generate this fire-vegetation feedback reinforced by the shift in fuel flammability.

\subsection{Implications for Restoration}

We recommend that the native species we identified as capable of resprouting are used for restoration planting in areas increasingly susceptible to fire, such as in wildland-urban interfaces (WUI) and regions predicted to experience more severe fire weather and fire danger. In NZ, these areas are concentrated in the eastern regions of both islands, part of the central region (Wellington and Nelson), and the Bay of Plenty [34].

Although most restoration plantings have been focused on keeping historic fidelity by using remnant natural ecosystems as a reference, and aiming to restore this vegetation composition and structure, this target is not always possible [66]. Restoration ecologists are increasingly recognising that human activities, climate change and species invasion profoundly transform the environment and even alter biochemical cycles. In these cases, the restoration of historical vegetation composition and structure may be unsustainable, and restoration efforts should be directed towards the recovery of ecological processes based on selected functional traits [66]. It has been internationally recognised that new fire regimes, altered as a consequence of climate change, should be incorporated into restoration 
strategies aimed at enhancing the resilience of newly restored landscapes [67]. Based on these concepts, we propose that by planting higher proportions of resprouters, it is possible to engineer more fire resilient restoration plantings (Box 1). The incorporation of the resprout trait in restoration plans is likely to be relevant not just in NZ but also in other historically non-fire-prone regions that are facing an increase in fire frequency. Despite the fact that most of the NZ canopy dominant species do not have the capacity to resprout, it is likely that the initial restoration planting will ameliorate the environment and are likely to be subsequently colonised by these non-resprouters. In addition, non- and weak-resprouters, and also high flammability species, can still be included in the restoration planting, but we suggest that this should be done in smaller densities in initial plantings.

Box 1. Conceptual model showing how plant communities abundant in species capable of resprouting tend to be more fire resilient and resistant to invasion. The Model is based on the present case study.

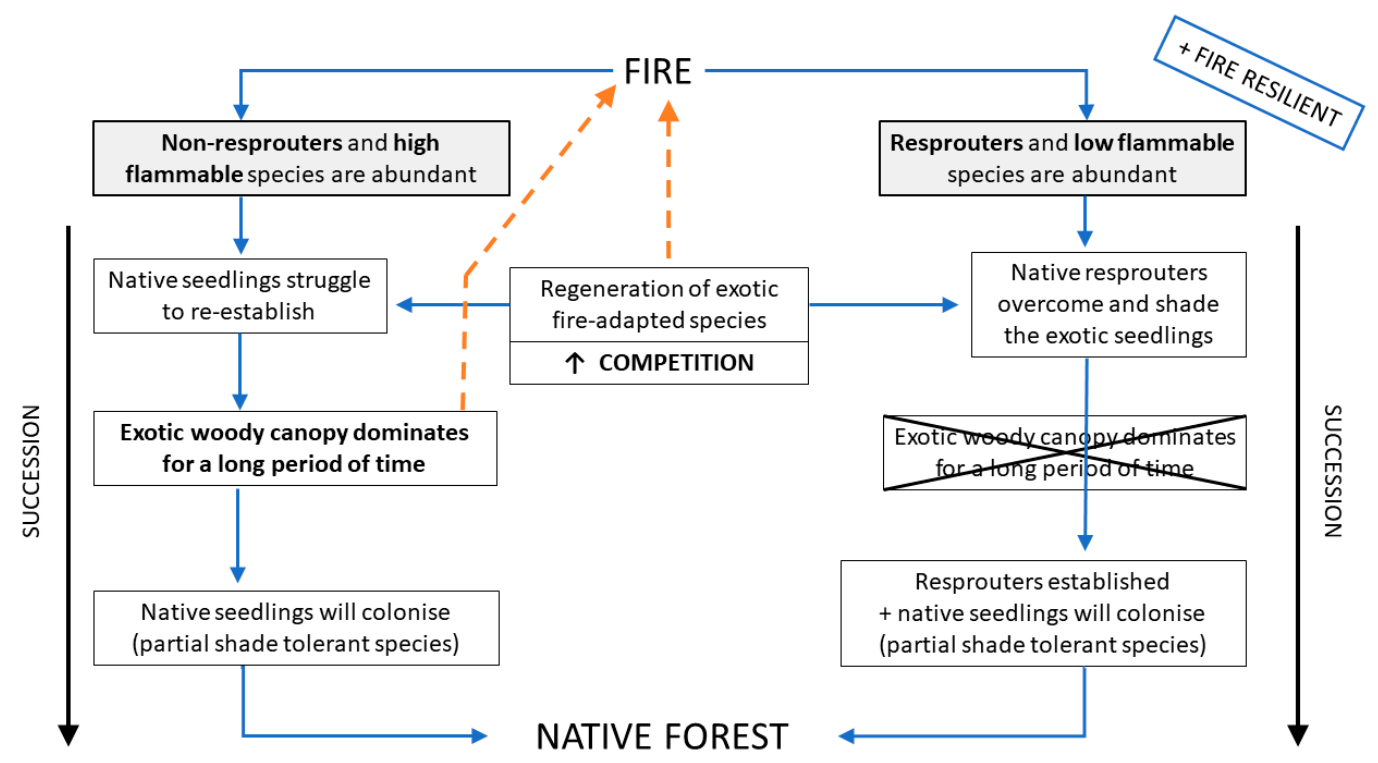

When fire affects a native plant community that lacks fire adaptation and is abundant in obligate seeders, this community will be more susceptible to invasion by exotic fire-adapted species, such as Ulex europaeus and Cytisus scoparius. If these exotic species regenerate and establish in the area, the subsequent establishment of native seedlings will be limited by strong competition. Subsequently, this novel community tends to be arrested in an exotic and highly flammable woody canopy for a long period of time, retarding the successional process. This novel community is generally more susceptible to new fire occurrence, due to its high flammability, and has the potential to generate a positive fire feedback. If the community does not burn again, and if sources of native seeds from unburnt patches are available, partial shade-tolerant native seedlings will slowly colonise the area following the successional trajectory back to the native forest. On the other hand, if resprouters are abundant in the native plant community, the resprouting trees will compete and overcome the exotic seedlings, reducing the probability of an exotic flammable canopy dominance. Therefore, communities abundant in resprouters tend to be more fire resilient and resistant to invasive species.

In addition, any restoration strategy following extensive wildfires should consider the establishment of green firebreaks [68]. The selection of ideal species for green firebreaks should be based on specific functional traits and, from an ecological perspective, low flammability and resprouting capability after fire are fundamental features [69]. In this sense, the native species with the best resprouting capacity, which are also low flammability species, such as F. excorticata, M. ramiflorus and G. littoralis, will probably have the potential to be used in firebreaks on the Port Hills and also in other fire-susceptible regions in NZ. 
Finally, the population of species classified as incapable of resprouting or weak resprouters should be monitored and, in case these species do not recover naturally, assisted restoration, such as the planting of seedlings, may be required in order to restore ecosystem biodiversity.

\section{Conclusions}

The present paper provides a large database of the resprouting capability of NZ woody species, including quantitative information on post-fire resprouting for some of the species. We expect that the data presented here will highlight the need for research into post-fire resprouting in vegetation types for which no information is available, promoting a broader understanding of this important functional trait $[5,11]$.

Future research into resprouting in NZ should focus on understanding why the same species (e.g., P. arboreus) can have great variation in resprouting proportions. We suggest that it varied as a function of fire intensity, but further investigation with a direct measurement of fire intensity is required to gain a deeper understanding. In addition, collecting quantitative resprouting data in different regions of NZ would be of value to improve and expand the database presented in this study.

We also showed that the composition and abundance of species are important predictors of the resprouting pattern at the community level. Predictions of post-fire responses in ecosystems that evolved with a low fire frequency are of strategic importance for planning restoration and conservation actions. From an ecological restoration perspective, we suggested that by planting higher proportions of resprouters and low flammable species, it is possible to engineer restored native forests to be more fire resilient and more resistant to invasion by exotic species (Box 1). The incorporation of the resprouting trait into restoration planning is likely to be relevant not just in NZ but also in other fire-sensitive forests that are currently under fire pressure.

Author Contributions: Conceptualization and methodology, D.A.N., A.M.C.T., T.J.C., P.E.J. and C.D.M.; formal analysis, A.M.C.T.; investigation, A.M.C.T.; resources, D.A.N. and P.E.J.; data curation, A.M.C.T.; writing-original draft preparation, A.M.C.T.; writing-review and editing, P.E.J., T.J.C. and D.A.N.; supervision, D.A.N., T.J.C., P.E.J. and C.D.M. All authors have read and agreed to the published version of the manuscript.

Funding: This research received no external funding. APC: University of Canterbury Library Open Access Fund. AMCT was supported by a PhD scholarship from the University of Canterbury.

Acknowledgments: We would like to thank the three reviewers for providing helpful comments. Thanks to the Summit Road Society and Christchurch City Council for the permission and support to develop this experiment in the conservation areas they manage. We also thank David Conder and Cristian Feher for the field assistance.

Conflicts of Interest: The authors declare no conflict of interest. 


\section{Appendix A}

Table A1. Resprouting capacity of New Zealand native trees and shrubs.

\begin{tabular}{|c|c|c|c|c|c|c|c|c|}
\hline Family & Species & Life-Form & $\begin{array}{c}\text { Burrows (1994) } \\
\text { [9] }\end{array}$ & $\begin{array}{c}\text { Wabing (2014) } \\
\text { [46] }\end{array}$ & $\begin{array}{c}\text { Glogoski (2017) } \\
\text { [70] }\end{array}$ & Others & $\begin{array}{l}\text { Current } \\
\text { Research }\end{array}$ & Comments \\
\hline Araliaceae & Meryta sinclairii (Hook.f.) Seem & tree & & & & No [71] & & $\begin{array}{l}\text { Appears to lack the capacity to } \\
\text { resprout after damage [71]. }\end{array}$ \\
\hline Araliaceae & Pseudopanax arboreus (L.f.) Allan & tree & & $100 \%(n=7)$ & & Yes [14] & $5 \%(n=43)$ & \\
\hline Araliaceae & $\begin{array}{l}\text { Pseudopanax crassifolius (Sol. ex } \\
\text { A.Cunn.) C.Koch }\end{array}$ & tree & Yes & & & Yes [14] & No $(n=1)$ & \\
\hline Araliaceae & Schefflera digitata J.R.Forst. et G.Forst. & tree & Yes & $100 \%(n=2)$ & & & Yes $(n=2)$ & \\
\hline Araucariaceae & Agathis australis (D.Don) Lindl. & tree & & & & Yes [19] & & $\begin{array}{c}\text { Resprout ability reported, } \\
\text { although the species is considered } \\
\text { a fire-sensitive [19]. }\end{array}$ \\
\hline Argophyllaceae & Corokia cotoneaster Raoul & shrub & Yes & & & & & \\
\hline Asparagaceae & Cordyline australis (Forst.f.) Endl. * & tree (monoc) & Yes & & & & $100 \%(n=20)$ & $\begin{array}{l}\text { Trees often resprouted, even wher } \\
\text { severely burned (current research) }\end{array}$ \\
\hline Asparagaceae & Cordyline spp. & tree (monoc) & & & & Yes [19] & & \\
\hline Asteraceae & Olearia avicenniifolia (Raoul) Hook.f. ** & tree & & & & & $0 \%(n=12)$ & \\
\hline Asteraceae & Olearia colensoi Hook.f. & shrub & & & & No [72] & & \\
\hline Asteraceae & Olearia ilicifolia Hook.f. & tree & & & & Yes [73] & & \\
\hline Asteraceae & Olearia rani (A.Cunn.) Druce & tree & & & & Yes [74] & & $\begin{array}{l}\text { Resprout after tree falls and storm } \\
\text { damage, but fire can decrease the } \\
\text { possibility of recovery from } \\
\text { resproutings [74]. }\end{array}$ \\
\hline Asteraceae & $\begin{array}{c}\text { Ozothammus leptophyllus (G.Forst.) } \\
\text { Breitw. et J.M.Ward }\end{array}$ & shrub & & & No & Yes $[19,73]$ & & May resprout from the base [73]. \\
\hline Corynocarpaceae & $\begin{array}{c}\text { Corynocarpus laevigatus J.R.Forst. et } \\
\text { G.Forst. }\end{array}$ & tree & Yes & & & Yes [71] & & $\begin{array}{c}\text { Resprouts may grow into new } \\
\text { trees when young trees are sawn } \\
\text { off at the base [9]. }\end{array}$ \\
\hline Cunoniaceae & Weinmannia racemosa L.f. & tree & Yes & & & Yes [19] & & \\
\hline Dicksoniaceae & Dicksonia squarrosa (G.Forst.) Swartz & tree fern & & & & Yes [75] & & \\
\hline Elaeocarpaceae & Aristotelia fruticosa Hook.f. & tree & & & Yes & & & \\
\hline
\end{tabular}


Table A1. Cont.

\begin{tabular}{|c|c|c|c|c|c|c|c|c|}
\hline Family & Species & Life-Form & $\begin{array}{c}\text { Burrows (1994) } \\
{[9]}\end{array}$ & $\begin{array}{l}\text { Wabing (2014) } \\
{[46]}\end{array}$ & $\begin{array}{c}\text { Glogoski (2017) } \\
{[70]}\end{array}$ & Others & $\begin{array}{l}\text { Current } \\
\text { Research }\end{array}$ & Comments \\
\hline Elaeocarpaceae & $\begin{array}{c}\text { Aristotelia serrata (J.R.Forst. et G.Forst.) } \\
\text { W.R.B.Oliv. }\end{array}$ & tree & Yes & $100 \%(n=9)$ & & Yes [19] & & $\begin{array}{c}\text { Resprouts may grow into new } \\
\text { trees when young trees are sawn } \\
\text { off the base [9]. }\end{array}$ \\
\hline Ericaceae & Dracophyllum acerosum Bergg. & tree & & & No & & & \\
\hline Ericaceae & $\begin{array}{l}\text { Dracophyllum longifolium (J.R.Forst et } \\
\text { G.Forst.) R.Br. }\end{array}$ & shrub & & & & No [72] & & \\
\hline Ericaceae & Dracophyllum subulatum Hook.f. & shrub & & & & No [76] & & \\
\hline Ericaceae & Dracophyllum spp. & shrub - tree & & & & No [19] & & \\
\hline Ericaceae & $\begin{array}{l}\text { Gaultheria macrostigma (Colenso) } \\
\text { D.J.Middleton }\end{array}$ & shrub & & & & Yes [16] & & \\
\hline Ericaceae & Gaultheria rupestris (L.f.) D.Don & shrub & & & & Yes [73] & & Resprouted from rhizomes [73]. \\
\hline Fabaceae & Sophora microphylla Aiton * & tree & Yes & & & & $25 \%(n=4)$ & $\begin{array}{l}\text { Resprouts may grow into new } \\
\text { trees, when young trees are sawn } \\
\text { off at the base [9]. Usually did not } \\
\text { resprout, even when lightly burnt } \\
\text { (current research). }\end{array}$ \\
\hline Fabaceae & Sophora prostrata Buchanan & shrub - tree & & & & Yes [15] & & $\begin{array}{l}40 \text { plants resprouted and were } \\
\text { tagged and } 30 \text { were still alive } 15 \\
\text { years after the fire [15]. }\end{array}$ \\
\hline Griseliniaceae & Griselinia littoralis Raoul & tree & Yes & $100 \%(n=4)$ & & Yes [71] & $50 \%(n=10)$ & $\begin{array}{l}\text { Resprouts when young trees are } \\
\text { sawn off at the base [9]. } \\
\text { Withstands fire and continues to } \\
\text { grow from basal stem sprouts [71] }\end{array}$ \\
\hline Lamiaceae & $\begin{array}{l}\text { Teucridium parvifolium (Hook.f.) } \\
\text { Kattari et Salmaki }\end{array}$ & tree & & $100 \%(n=5)$ & & & & \\
\hline Lamiaceae & Vitex lucens Kirk & tree & & & & Yes [77] & & $\begin{array}{l}\text { Resprouts after general } \\
\text { disturbance, nothing specific abou } \\
\text { fire response [77]. }\end{array}$ \\
\hline Lauraceae & Beilschmiedia spp. & tree & & & & Yes [19] & & $\begin{array}{l}\text { Although the resprout ability, is } \\
\text { considered fire-sentive species [19] }\end{array}$ \\
\hline Lauraceae & $\begin{array}{c}\text { Beilschmiedia tawa (A.Cunn.) Benth. et } \\
\text { Hook.f. ex Kirk }\end{array}$ & tree & Yes & & & Yes [78] & & $\begin{array}{c}\text { Resprouts may grow into new } \\
\text { trees when young trees are sawn } \\
\text { off at the base [9]. Resprouted afte } \\
\text { volcanic activity [78]. }\end{array}$ \\
\hline Loganiaceae & Geniostoma ligustrifolium A.Cunn. & shrub & & & & Yes [74] & & $\begin{array}{l}\text { Resprout after tree falls and storm } \\
\text { damage, but fire can decrease the } \\
\text { possibility of recovery from } \\
\text { resprouts [74]. }\end{array}$ \\
\hline Malvaceae & $\begin{array}{l}\text { Hoheria glabrata Sprague et } \\
\text { Summerhayes }\end{array}$ & tree & & & & Yes [73] & & $\begin{array}{l}\text { Probably can resprout from burnt } \\
\text { stumps [73]. }\end{array}$ \\
\hline
\end{tabular}


Table A1. Cont.

\begin{tabular}{|c|c|c|c|c|c|c|c|c|}
\hline Family & Species & Life-Form & $\begin{array}{c}\text { Burrows (1994) } \\
{[9]}\end{array}$ & $\begin{array}{c}\text { Wabing (2014) } \\
\text { [46] }\end{array}$ & $\begin{array}{c}\text { Glogoski (2017) } \\
\text { [70] }\end{array}$ & Others & $\begin{array}{l}\text { Current } \\
\text { Research }\end{array}$ & Comments \\
\hline Malvaceae & Hoheria sexstylosa Colenso & tree & Yes & & & & & $\begin{array}{c}\text { Resprouts may grow into new } \\
\text { trees when young trees are sawn } \\
\text { off at the base [9]. }\end{array}$ \\
\hline Malvaceae & Plagianthus regius (Poit.) Hochr. ${ }^{* *}$ & tree & & & & & $10 \%(n=11)$ & \\
\hline Monimiaceae & Hedycarya arborea J.R.Forst. et G.Forst & tree & & & & Yes [71] & & $\begin{array}{l}\text { Vigorous basal and stem sprouts } \\
\text { (general disturbance, nothing } \\
\text { specific about fire response) [71]. }\end{array}$ \\
\hline Myrtaceae & Kunzea robusta de Lange et Toelken & tree & No & $0 \%(n=6)$ & & No $[15,19]$ & $0 \%(n=39)$ & $\begin{array}{l}\text { Does not resprout, even when } \\
\text { lightly burnt (current research). }\end{array}$ \\
\hline Myrtaceae & $\begin{array}{l}\text { Leptospermum scoparium J.R.Forst. et } \\
\text { G.Forst. }\end{array}$ & tree & No & & No & No & & $\begin{array}{c}\text { Inability to produce basal sprouts } \\
\text { after fire [9]. }\end{array}$ \\
\hline Myrtaceae & Metrosideros umbellata Cav. & tree & & & & No [79] & & $\begin{array}{l}\text { Trees do not recover from forest } \\
\text { fires [79]. }\end{array}$ \\
\hline Myrtaceae & Metrosideros excelsa Sol. ex Gaertn. & tree & & & & No [80] & & $\begin{array}{l}\text { Small percentage can resprout } \\
\text { from epicormic buds after } \\
\text { volcanism [80]. }\end{array}$ \\
\hline Nothofagaceae & $\begin{array}{l}\text { Fuscospora cliffortioides (Hook.f.) } \\
\text { Heenan et Smissen }\end{array}$ & tree & & & No & No [81] & & $\begin{array}{l}\text { NZ beeches do not resprout after } \\
\text { fire [81]. }\end{array}$ \\
\hline Nothofagaceae & $\begin{array}{c}\text { Fuscospora solandri (Hook.f.) Heenan et } \\
\text { Smissen }\end{array}$ & tree & & & & No [81] & & $\begin{array}{l}\text { Virtually all mountain beech trees } \\
\text { scorched by fire died within five } \\
\text { years [14]. NZ beeches do not } \\
\text { resprout after fire [81]. }\end{array}$ \\
\hline Nothofagaceae & Fuscospora spp. & tree & & & & No $[14,19,81]$ & & $\begin{array}{l}\text { NZ beeches do not resprout after } \\
\text { fire [81]. Even low temperature } \\
\text { ground fires often kill most beech } \\
\text { trees and seedlings in New } \\
\text { Zealand }[14,19]\end{array}$ \\
\hline Nothofagaceae & $\begin{array}{c}\text { Lophozonia menziesii (Hook.f.) Heenan } \\
\text { et Smissen }\end{array}$ & tree & & & & No $[19,81]$ & & $\begin{array}{l}\text { NZ beeches do not resprout after } \\
\text { fire [81]. }\end{array}$ \\
\hline Onagraceae & $\begin{array}{l}\text { Fuchsia excorticata (J.R.Forst. et } \\
\text { G.Forst.) L.f. }\end{array}$ & tree & Yes & $100 \%(n=9)$ & & Yes & $100 \%(n=9)$ & $\begin{array}{l}\text { Trees burnt to the ground and } \\
\text { felled by wind regenerate from } \\
\text { resprouts [9]. After fire, trees often } \\
\text { resprouted abundantly from the } \\
\text { base (current research). }\end{array}$ \\
\hline Phyllocladaceae & Phyllocladus alpinus Hook.f. & shrub & Yes & & & Yes [72] & & Epicormic resprout [72]. \\
\hline Phyllocladaceae & Phyllocladus spp. & tree & & & & No [19] & & \\
\hline Pittosporaceae & Pittosporum eugenioides A.Cunn. & tree & & $87 \%(n=16)$ & & & & \\
\hline
\end{tabular}


Table A1. Cont.

\begin{tabular}{|c|c|c|c|c|c|c|c|c|}
\hline Family & Species & Life-Form & $\begin{array}{l}\text { Burrows (1994) } \\
{[9]}\end{array}$ & $\begin{array}{l}\text { Wabing (2014) } \\
\text { [46] }\end{array}$ & $\begin{array}{c}\text { Glogoski (2017) } \\
{[70]}\end{array}$ & Others & $\begin{array}{l}\text { Current } \\
\text { Research }\end{array}$ & Comments \\
\hline Pittosporaceae & Pittosporum tenuifolium Sol. ex Gaertn & tree & & & & Yes [19] & & \\
\hline Pittosporaceae & Pittosporum tenuifolium/eugenioides & tree & & & & & $3 \%(n=35)$ & $\begin{array}{l}\text { Two slightly burnt plants } \\
\text { resprouted, but the resprouts dried } \\
\text { out and died between } 5 \text { and } 10 \\
\text { months after being burnt (current } \\
\text { research). }\end{array}$ \\
\hline Pittosporaceae & Pittosporum sp. & tree & & $100 \%(n=2)$ & & & & \\
\hline Plantaginaceae & Veronica salicifolia G.Forst. ** & tree & & & & & $0 \%(n=14)$ & \\
\hline Plantaginaceae & Veronica spp. (hebe) & tree & & & & No [73] & & \\
\hline Podocarpaceae & $\begin{array}{l}\text { Dacrycarpus dacrydioides (A.Rich.) de } \\
\text { Laub. }\end{array}$ & tree & & & & No [19] & & \\
\hline Podocarpaceae & Dacrydium cupressinum Lamb. & tree & & & & No [19] & & \\
\hline Podocarpaceae & Halocarpus bidwillii (Kirk) Quinn & shrub & Yes & & & & & \\
\hline Podocarpaceae & Halocarpus spp. & tree & & & & No [19] & & \\
\hline Podocarpaceae & Podocarpus spp. & tree & No & & & & & \\
\hline Podocarpaceae & Podocarpus totara G.Benn. ex D.Don & tree & & $71 \%(n=7)$ & & No [19] & No $(n=3)$ & \\
\hline Podocarpaceae & Prumnopitys taxifolia (D.Don) de Laub. & tree & & & & No [19] & & \\
\hline Polygonaceae & Muehlenbeckia astonii Petrie & shrub & & & & Yes [82] & & $\begin{array}{l}\text { Resprouts after general } \\
\text { disturbance, nothing specific about } \\
\text { fire response [82]. }\end{array}$ \\
\hline Primulaceae & Myrsine australis (A.Rich.) Allan & tree & & & & Yes [83] & & $\begin{array}{l}\text { Trees damaged near the base } \\
\text { produce abundant resprouts [9]. } \\
\text { Resprouts after wind-storm, and } \\
\text { probably resprout from roots after } \\
\text { fire [83]. }\end{array}$ \\
\hline Rhamnaceae & Discaria toumatou Raoul & shrub-tree & Yes & & Yes $35-65 \%$ & Yes $[19,70]$ & & $\begin{array}{l}\text { Between approximately } 35 \text { and } \\
65 \% \text {, depending on plant size and } \\
\text { time since the fire event [70]. }\end{array}$ \\
\hline Rosaceae & Rubus cissoides A.Cunn. & tree & & $100 \%(n=1)$ & & & & \\
\hline Rousseaceae & $\begin{array}{c}\text { Carpodetus serratus J.R.Forst. et } \\
\text { G.Forst. }\end{array}$ & tree & Yes & $90 \%(n=10)$ & & Yes [14] & & \\
\hline Rubiaceae & Coprosma ciliata Hook.f. & shrub & & & & Yes [16] & & \\
\hline Rubiaceae & Coprosma crassifolia Colenso & shrub & & & & $7 \%(n=163)[84]$ & & \\
\hline Rubiaceae & $\begin{array}{l}\text { Coprosma dumosa (Cheeseman) } \\
\text { G.T.Jane }\end{array}$ & tree & & $100 \%(n=1)$ & & & & \\
\hline
\end{tabular}


Table A1. Cont.

\begin{tabular}{|c|c|c|c|c|c|c|c|c|}
\hline Family & Species & Life-Form & $\begin{array}{c}\text { Burrows (1994) } \\
{[9]}\end{array}$ & $\begin{array}{c}\text { Wabing (2014) } \\
{[46]}\end{array}$ & $\begin{array}{c}\text { Glogoski (2017) } \\
\text { [70] }\end{array}$ & Others & $\begin{array}{l}\text { Current } \\
\text { Research }\end{array}$ & Comments \\
\hline Rubiaceae & Corposma sp. aff. intertexa G.Simpson & shrub & & & & Yes [17] & & $\begin{array}{l}\text { Resprouts from the burnt base and } \\
\text { from underground rhizomes [17]. }\end{array}$ \\
\hline Rubiaceae & Coprosma microcarpa Hook.f. & tree & & & & Yes [14] & & \\
\hline Rubiaceae & Coprosma propinqua A.Cunn & shrub & & & Yes & $\begin{array}{c}36 \%(n=56)[84] \\
\text { Yes [17] }\end{array}$ & & $\begin{array}{l}\text { Resprouts from the burnt base and } \\
\text { from underground rhizomes [17]. }\end{array}$ \\
\hline Rubiaceae & $\begin{array}{c}\text { Coprosma pseudocuneata Garn.-Jones et } \\
\text { R.Elder }\end{array}$ & tree & & & & Yes [14] & & \\
\hline Rubiaceae & Coprosma rhamnoides A.Cunn. & tree & & & & Yes [14] & & \\
\hline Rubiaceae & Coprosma spp. & shrub & & & & Yes $[9,85]$ & & \\
\hline Rubiaceae & Coprosma cf. rubra ${ }^{* *}$ & shrub & & & & & $60 \%(n=5)$ & \\
\hline Rubiaceae & Coprosma robusta/lucida ** & tree & & & & & $64 \%(n=33)$ & $\begin{array}{l}\text { Resprouted-basal and epicormic } \\
\text { (current research) }\end{array}$ \\
\hline Rubiaceae & $\begin{array}{c}\text { Coprosma serrulata Hook.f. ex } \\
\text { Buchanan }\end{array}$ & shrub & & & & Yes [73] & & $\begin{array}{l}\text { Resprouted from surviving base } \\
\text { [73]. }\end{array}$ \\
\hline Sapindaceae & Alectryon excelsus Gaertn. & tree & Yes & & & & & $\begin{array}{c}\text { Resprouts may grow into new } \\
\text { trees when young trees are sawn } \\
\text { off the base [9]. }\end{array}$ \\
\hline Violaceae & Melicytus alpinus (Kirk) Garn.-Jones & shrub & Yes & & & & & \\
\hline Violaceae & $\begin{array}{l}\text { Melicytus ramiflorus J.R.Forst. et } \\
\text { G.Forst. }\end{array}$ & tree & Yes & $93(n=29)$ & & Yes [19] & $69 \%(n=126)$ & $\begin{array}{c}\text { Resprouted-basal and epicormic } \\
\text { (current research) }\end{array}$ \\
\hline Violaceae & Melicytus macrophyllus A.Cunn. & tree & & & & Yes [74] & & $\begin{array}{l}\text { Resprouts after tree falls and storm } \\
\text { damage, but fire can decrease the } \\
\text { possibility of recovery from } \\
\text { resprouting [74]. }\end{array}$ \\
\hline Winteraceae & Pseudowintera colorata (Raoul) Dandy & tree & & $77 \%(n=57)$ & & & & \\
\hline
\end{tabular}

Note: * Prior to this investigation, there was no quantitative information on resprouting for the species. ${ }^{* *}$ Prior to this investigation, there was no information on resprouting for the species. 


\section{Appendix B}

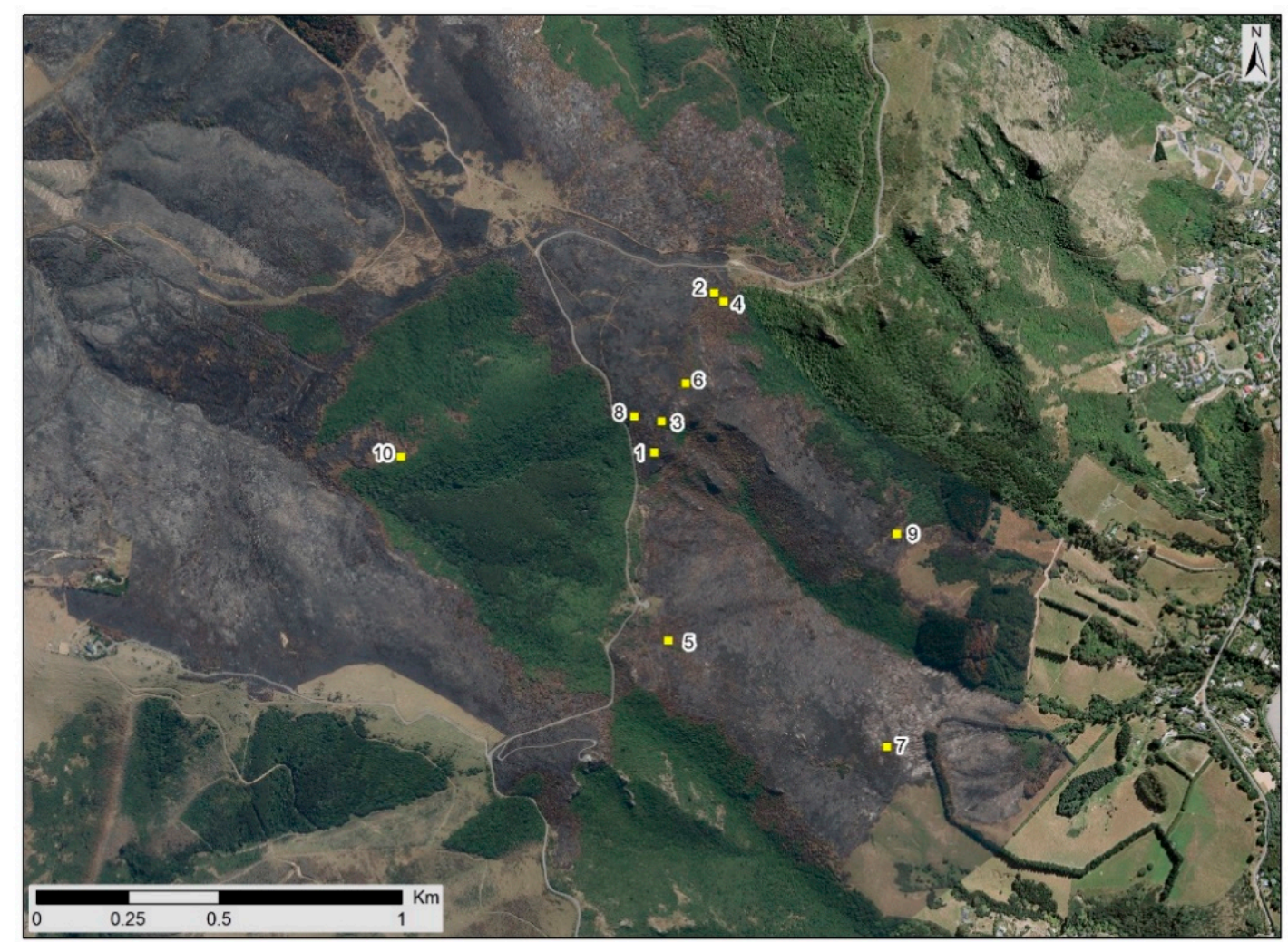

(a)

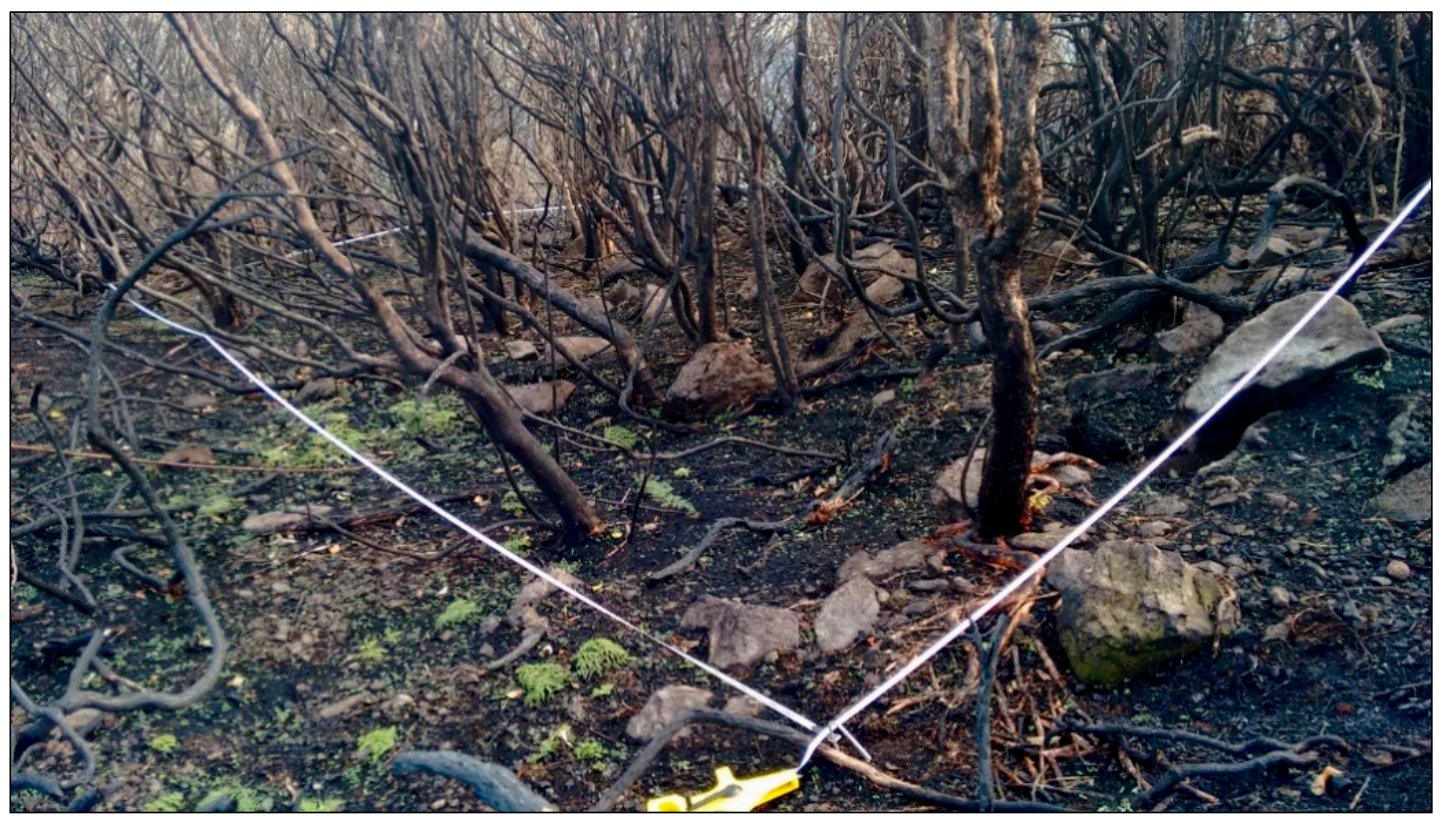

(b)

Figure A1. Location of the sampling plots in the burned landscape (a). Photograph of one of the sampling plots $(\mathbf{b})$. 


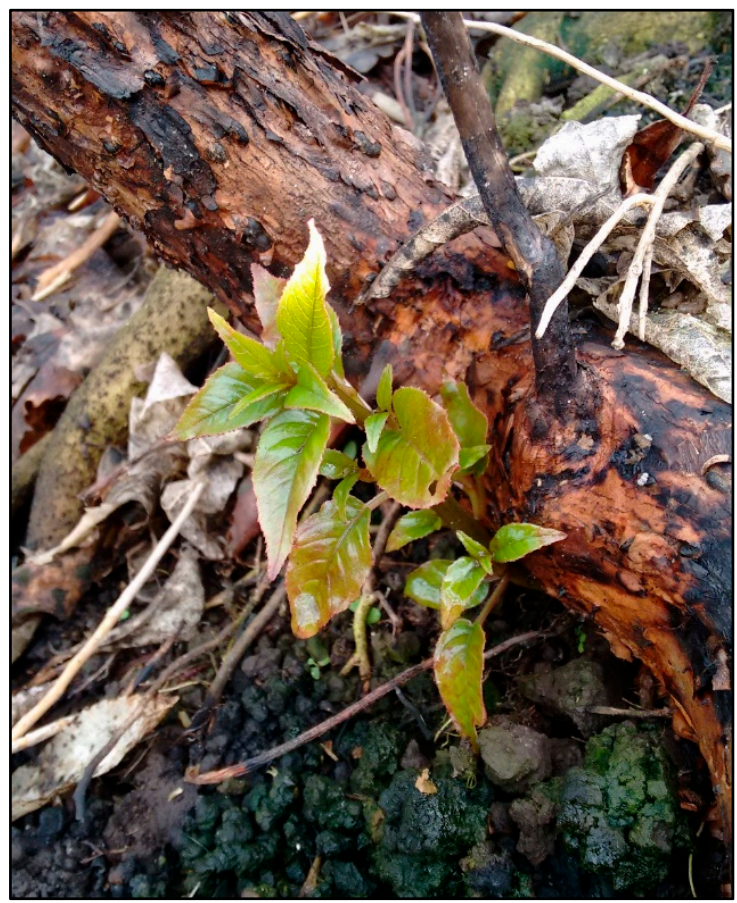

Figure A2. Fuchsia excorticata resprouting.

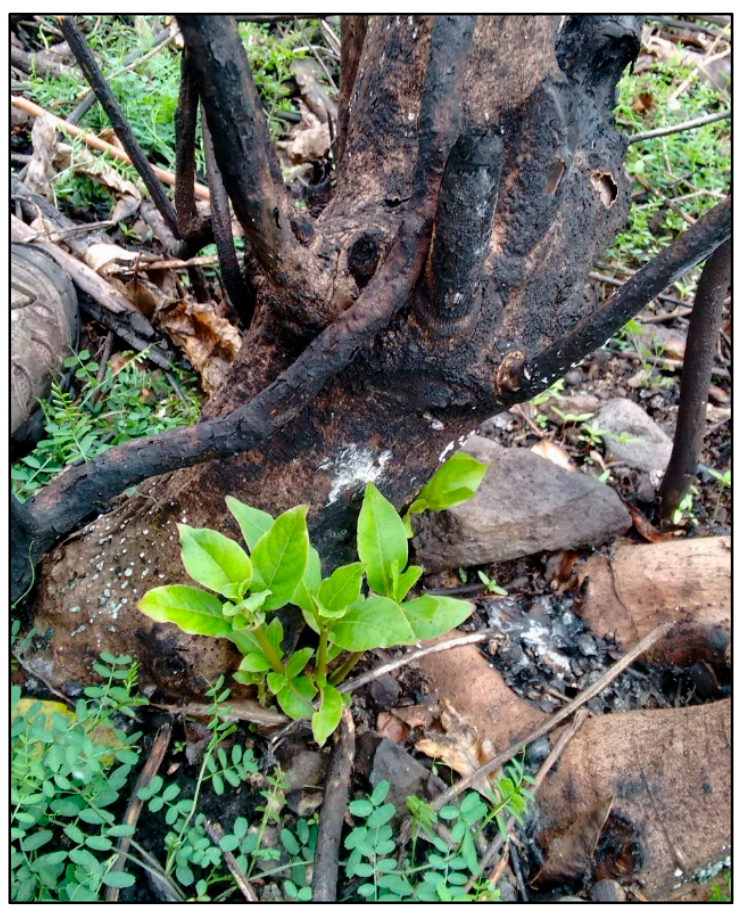

Figure A3. Coprosma robusta/lucida resprouting. 


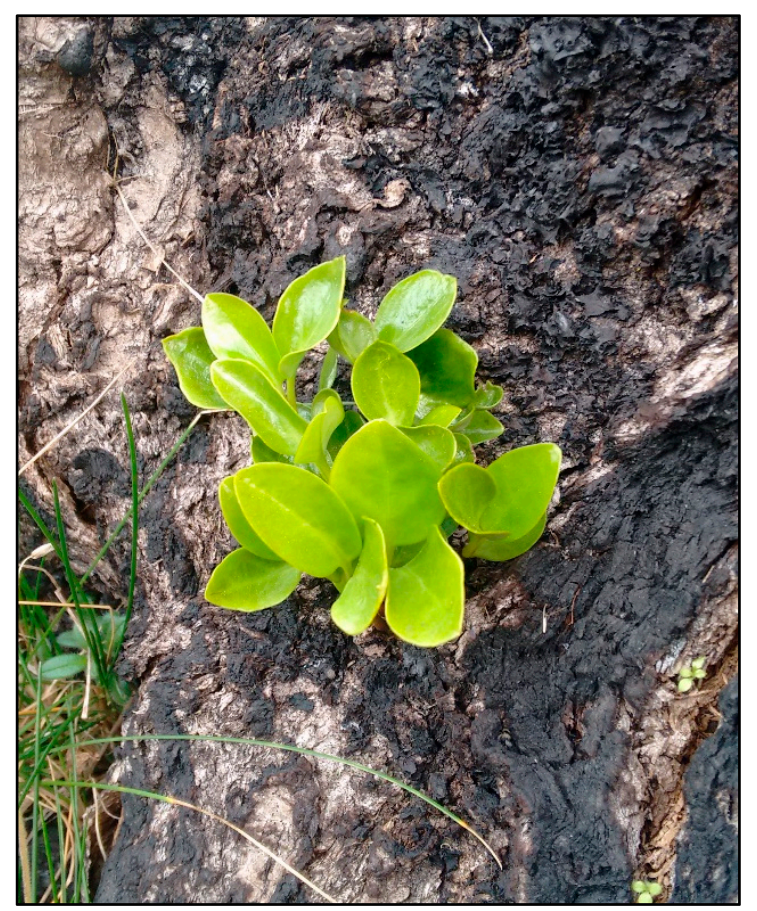

Figure A4. Griselinia littoralis resprouting.

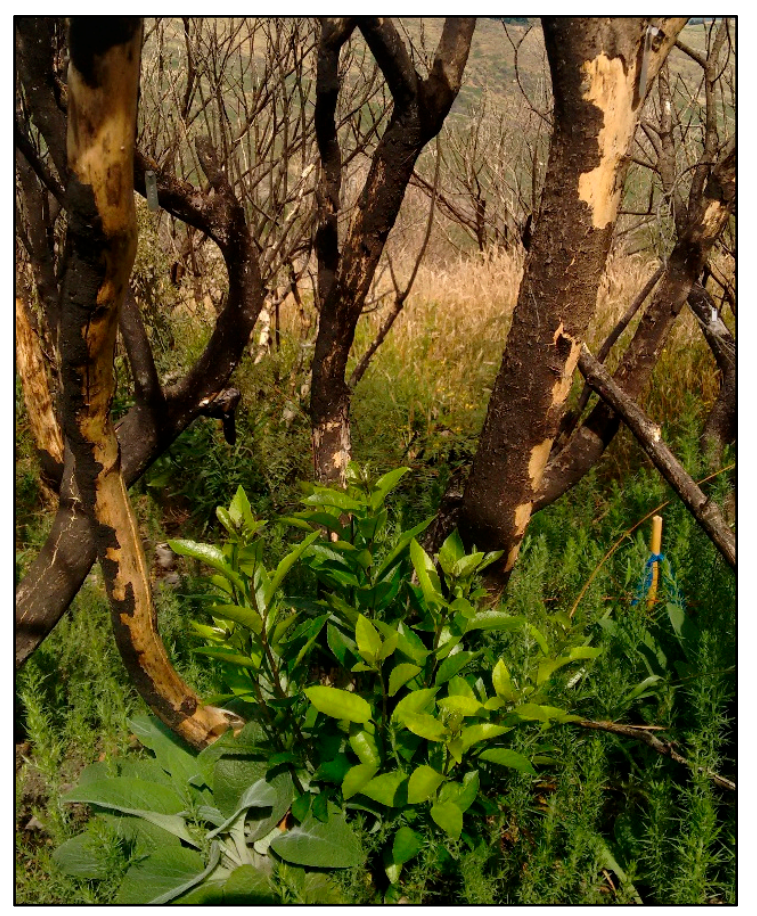

Figure A5. Melicytus ramiflorus resprouting and Ulex europaeus seedlings. 


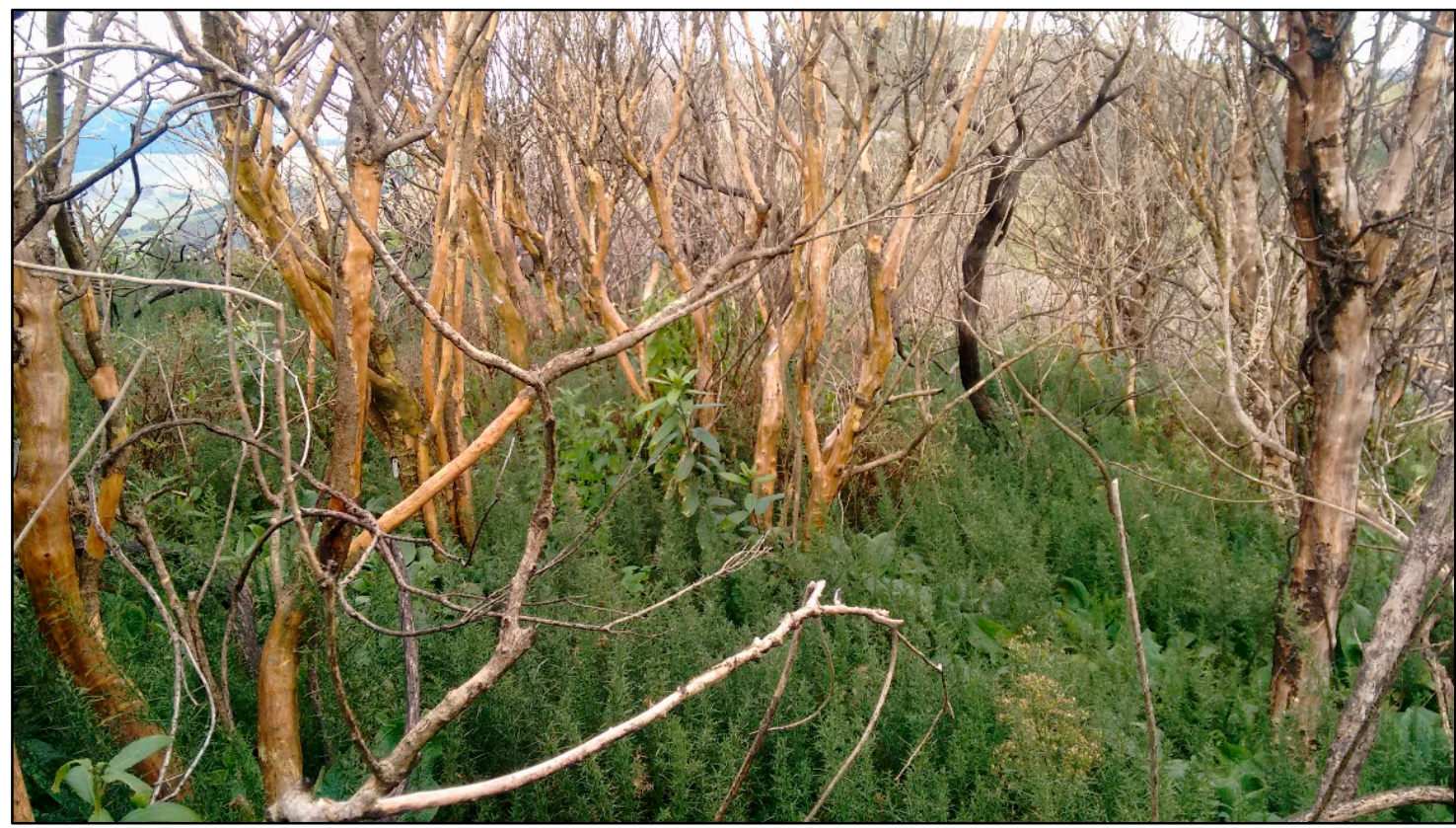

Figure A6. High density of Ulex europaeus seedlings regenerating under the burnt bush canopy. In the center of the picture, a basal resprout of Melicytus ramiflorus overcame the thick layer of $U$. europaeus seedlings. The photography was taken in plot 3,18 months after the fire.

\section{References}

1. Bowman, D.M.; Balch, J.K.; Artaxo, P.; Bond, W.J.; Carlson, J.M.; Cochrane, M.A.; D'Antonio, C.M.; DeFries, R.S.; Doyle, J.C.; Harrison, S.P. Fire in the Earth system. Science 2009, 324, 481-484. [CrossRef]

2. Pausas, J.G.; Keeley, J.E. A burning story: The role of fire in the history of life. BioScience 2009, 59, 593-601. [CrossRef]

3. Bond, W.J.; Midgley, J.J. Ecology of sprouting in woody plants: The persistence niche. Trends Ecol. Evol. 2001, 16, 45-51. [CrossRef]

4. Vieira, D.L.; Scariot, A. Principles of natural regeneration of tropical dry forests for restoration. Restor. Ecol. 2006, 14, 11-20. [CrossRef]

5. Vesk, P.A.; Westoby, M. Sprouting ability across diverse disturbances and vegetation types worldwide. J. Ecol. 2004, 92, 310-320. [CrossRef]

6. Clarke, P.J.; Lawes, M.J.; Murphy, B.P.; Russell-Smith, J.; Nano, C.E.M.; Bradstock, R.; Enright, N.J.; Fontaine, J.B.; Gosper, C.R.; Radford, I.; et al. A synthesis of postfire recovery traits of woody plants in Australian ecosystems. Sci. Total Environ. 2015, 534, 31-42. [CrossRef] [PubMed]

7. Clarke, P.J.; Lawes, M.J.; Midgley, J.J.; Lamont, B.B.; Ojeda, F.; Burrows, G.E.; Enright, N.J.; Knox, K.J. Resprouting as a key functional trait: How buds, protection and resources drive persistence after fire. New Phytol. 2013, 197, 19-35. [CrossRef] [PubMed]

8. Moreira, B.; Tormo, J.; Pausas, J.G. To resprout or not to resprout: Factors driving intraspecific variability in resprouting. Oikos 2012, 121, 1577-1584. [CrossRef]

9. Burrows, C.J. Do New Zealand forest trees regenerate from sprouts. Canterb. Bot. Soc. J. 1994, 28, 63-68.

10. Pausas, J.G.; Pratt, R.B.; Keeley, J.E.; Jacobsen, A.L.; Ramirez, A.R.; Vilagrosa, A.; Paula, S.; Kaneakua-Pia, I.N.; Davis, S.D. Towards understanding resprouting at the global scale. New Phytol. 2016, 209, 945-954. [CrossRef]

11. Bond, W.J.; Midgley, J.J. The evolutionary ecology of sprouting in woody plants. Int. J. Plant Sci. 2003, 164, S103-S114. [CrossRef]

12. Kitzberger, T.; Perry, G.L.W.; Paritsis, J.; Gowda, J.H.; Tepley, A.J.; Holz, A.; Veblen, T.T. Fire-vegetation feedbacks and alternative states: Common mechanisms of temperate forest vulnerability to fire in southern South America and New Zealand. N. Z. J. Bot. 2016, 54, 247-272. [CrossRef]

13. Mason, N.W.; Frazao, C.; Buxton, R.P.; Richardson, S.J. Fire form and function: Evidence for exaptive flammability in the New Zealand flora. Plant Ecol. 2016, 217, 645-659. [CrossRef] 
14. Wiser, S.K.; Allen, R.B.; Platt, K.H. Mountain beech forest succession after a fire at Mount Thomas Forest, Canterbury, New Zealand. N. Z. J. Bot. 1997, 35, 505-515. [CrossRef]

15. Richardson, S.J.; King, S.; Rose, A.B.; McGlone, M.S.; Holdaway, R.J. Post-fire recovery of a dryland forest remnant in the Wither Hills, Marlborough. N. Z. J. Ecol. 2018, 42, 222-228. [CrossRef]

16. Johnson, P.N. Vegetation recovery after fire on a southern New Zealand peatland. N. Z. J. Bot. 2001, 39, 251-267. [CrossRef]

17. Timmins, S.M. Wetland vegetation recovery after fire: Eweburn Bog, Te Anau, New Zealand. N. Z. J. Bot. 1992, 30, 383-399. [CrossRef]

18. Ogden, J.; Basher, L.; McGlone, M.A. Botanical briefing Fire, Forest Regeneration and Links with Early Human Habitation: Evidence from New Zealand. Ann. Bot. 1998, 81, 687-696. [CrossRef]

19. Perry, G.L.; Wilmshurst, J.M.; McGlone, M.S. Ecology and long-term history of fire in New Zealand. N. Z. J. Ecol. 2014, 38, 157-176.

20. Cecil, D.J.; Buechler, D.E.; Blakeslee, R.J. Gridded lightning climatology from TRMM-LIS and OTD: Dataset description. Atmos. Res. 2014, 135-136, 404-414. [CrossRef]

21. Christian, H.J.; Blakeslee, R.J.; Boccippio, D.J.; Boeck, W.L.; Buechler, D.E.; Driscoll, K.T.; Boeck, W.L.; Buechler, D.E.; Driscoll, K.T.; Goodman, S.J.; et al. Global frequency and distribution of lightning as observed from space by the Optical Transient Detector. J. Geophys. Res. Atmos. 2003, 108, ACL-4. [CrossRef]

22. Wyse, S.V.; Perry, G.L.; O'Connell, D.M.; Holland, P.S.; Wright, M.J.; Hosted, C.L.; Whitelock, S.L.; Geary, I.J.; Maurin, K.J.; Curran, T.J. A quantitative assessment of shoot flammability for 60 tree and shrub species supports rankings based on expert opinion. Int. J. Wildland Fire 2016, 25, 466-477. [CrossRef]

23. McGlone, M. Polynesian deforestation of New Zealand: A preliminary synthesis. Archaeol. Ocean. 1983, 18, 11-25. [CrossRef]

24. Stevens, G.; McGlone, M.; McCulloch, B. Prehistoric New Zealand; Royal New Zealand Foundation of the Blind: Auckland, New Zealand, 1995.

25. Ewers, R.M.; Kliskey, A.D.; Walker, S.; Rutledge, D.; Harding, J.S.; Didham, R.K. Past and future trajectories of forest loss in New Zealand. Biol. Conserv. 2006, 133, 312-325. [CrossRef]

26. Pawson, E.; Brooking, T. Making a New Land: Environmental Histories of New Zealand; University of Otago Press: Dunedin, New Zealand, 2013.

27. Wilson, H.D. Plant Life on Banks Peninsula; Manuka Press: Cromwell, New Zealand, 2013.

28. Wilson, H.D. Natural History of Banks Peninsula; Canterbury University Press: Christchurch, New Zealand, 2009.

29. Wilson, H.D. Vegetation of Banks Peninsula. In The Natural History of Canterbury, 3rd ed.; Winterbourn, M., Knox, G., Burrows, C., Marsden, I., Eds.; Canterbury University Press: Christchurch, New Zealand, 2008; pp. 251-278.

30. Wyse, S.V.; Wilmshurst, J.M.; Burns, B.R.; Perry, G.L. New Zealand forest dynamics: A review of past and present vegetation responses to disturbance, and development of conceptual forest models. N. Z. J. Ecol. 2018, 42, 87-106. [CrossRef]

31. Perry, G.L.; Wilmshurst, J.M.; Ogden, J.; Enright, N.J. Exotic mammals and invasive plants alter fire-related thresholds in southern temperate forested landscapes. Ecosystems 2015, 18, 1290-1305. [CrossRef]

32. Tepley, A.J.; Thomann, E.; Veblen, T.T.; Perry, G.L.W.; Holz, A.; Paritsis, J.; Kitzberger, T.; Anderson-Teixeira, K.J. Influences of fire-vegetation feedbacks and post-fire recovery rates on forest landscape vulnerability to altered fire regimes. J. Ecol. 2018, 106, 1925-1940. [CrossRef]

33. Anderson, S.A.; Doherty, J.J.; Pearce, H.G. Wildfires in New Zealand from 1991 to 2007. N. Z. J. For. 2008, 53, 19-22.

34. Pearce, H.G.; Clifford, V. Fire weather and climate of New Zealand. N. Z. J. For. 2008, 53, 13-18.

35. Pearce, H.G. The 2017 Port Hills wildfires-A window into New Zealand's fire future? Aust. J. Disaster Trauma Stud. 2018, 22, 35-50.

36. Wilson, H.D. Banks Ecological Region Protected Natural Areas Programme Survey Report 21; Department of Conservation: Christchurch, New Zealand, 1992.

37. Gill, A.M.; Bradstock, R. A national register for the fire responses of plant species. Cunninghamia 1992, 2, 653-660.

38. McCune, B.; Grace, J.B.; Urban, D.L. Analysis of Ecological Communities; MjM Software Design: Lincoln, OR, USA, 2002; Volume 28. 
39. Legendre, P.; Legendre, L.F. Numerical Ecology; Elsevier: Amsterdam, The Netherlands, 2012.

40. Burrows, C.J. Fruit types and seed dispersal modes of woody plants in Ahuriri Summit Bush, Port Hills, western Banks Peninsula, Canterbury, New Zealand. N. Z. J. Bot. 1994, 32, 169-181. [CrossRef]

41. Oksanen, J. Multivariate analysis of ecological communities in R: Vegan tutorial. R Package Vers. 2011, 1, $1-43$.

42. Veblen, T.T.; Donoso, C.; Kitzberger, T.; Rebertus, A.J. Ecology of southern Chilean and Argentinean Nothofagus forests. In The Ecology and Biogeography of Nothofagus Forests; Veblen, T.T., Hill, R.S., Read, J., Eds.; Yale University Press: New Heaven, CT, USA, 1996; pp. 93-353.

43. Read, J.; Brown, M.J. Ecology of Australian Nothofagus forests. In The Ecology and Biogeography of Nothofagus Forests; Veblen, T.T., Hill, R.S., Read, J., Eds.; Yale University Press: New Heaven, CT, USA, 1996; pp. 131-181.

44. Pausas, J.G.; Keeley, J.E. Evolutionary ecology of resprouting and seeding in fire-prone ecosystems. New Phytol. 2014, 204, 55-65. [CrossRef]

45. Keeley, J.E.; Pausas, J.G.; Rundel, P.W.; Bond, W.J.; Bradstock, R.A. Fire as an evolutionary pressure shaping plant traits. Trends Plant Sci. 2011, 16, 406-411. [CrossRef]

46. Wabnig, T. Case Study at Hinewai-Reserve: Post-fire Assessment of the Resprouting Ability of some New Zealand Native Woody Plants. Master's Thesis, Natural Resources Management and Ecological Engineering, Lincoln University, Lincoln, New Zealand, 2014.

47. Nicholson, A.; Prior, L.D.; Perry, G.L.W.; Bowman, D.M.J.S. High post-fire mortality of resprouting woody plants in Tasmanian Mediterranean-type vegetation. Int. J. Wildland Fire 2017, 26, 532. [CrossRef]

48. Kauffman, J.B. Survival by sprouting following fire in tropical forests of the eastern Amazon. Biotropica 1991, 23, 219-224. [CrossRef]

49. Clarke, P.; Knox, K.J.; Campbell, M.L.; Copeland, L.M. Post-fire recovery of woody plants in the New England Tableland Bioregion. Cunninghamia 2009, 11, 221-239.

50. Su, W.-H.; Shi, Z.; Zhou, R.; Zhao, Y.-J.; Zhang, G.-F. The role of fire in the Central Yunnan Plateau ecosystem, southwestern China. For. Ecol. Manag. 2015, 356, 22-30. [CrossRef]

51. Reyes, O.; Casal, M.; Rego, F.C. Resprouting ability of six Atlantic shrub species. Folia Geobotanica 2009, 44, 19-29. [CrossRef]

52. Miller, P.; Kauffman, J. Seedling and sprout response to slash-and-burn agriculture in a Tropical Deciduous Forest 1. Biotropica 1998, 30, 538-546. [CrossRef]

53. Kennard, D.; Gould, K.; Putz, F.; Fredericksen, T.; Morales, F. Effect of disturbance intensity on regeneration mechanisms in a tropical dry forest. For. Ecol. Manag. 2002, 162, 197-208. [CrossRef]

54. Ellair, D.P.; Platt, W.J. Fuel composition influences fire characteristics and understorey hardwoods in pine savanna. J. Ecol. 2013, 101, 192-201. [CrossRef]

55. Burrows, C.J. Germination behaviour of seeds of the New Zealand woody species Alectryon excelsus, Corynocarpus laevigatus, and Kunzea ericoides. N. Z. J. Bot. 1996, 34, 489-498. [CrossRef]

56. Allen, R.; Partridge, T.; Lee, W.; Efford, M. Ecology of Kunzea ericoides (A. Rich.) J. Thompson (kanuka) in east Otago, New Zealand. N. Z. J. Bot. 1992, 30, 135-149. [CrossRef]

57. Grady, J.M.; Hoffmann, W.A. Caught in a fire trap: Recurring fire creates stable size equilibria in woody resprouters. Ecology 2012, 93, 2052-2060. [CrossRef]

58. Hoffmann, W.A.; Geiger, E.L.; Gotsch, S.G.; Rossatto, D.R.; Silva, L.C.; Lau, O.L.; Haridasan, M.; Franco, A.C. Ecological thresholds at the savanna-forest boundary: How plant traits, resources and fire govern the distribution of tropical biomes. Ecol. Lett. 2012, 15, 759-768. [CrossRef]

59. Bellingham, P.J.; Sparrow, A.D. Resprouting as a life history strategy in woody plant communities. Oikos 2000, 89, 409-416. [CrossRef]

60. de Magalhaes, R.M.; Schwilk, D.W. Leaf traits and litter flammability: Evidence for non-additive mixture effects in a temperate forest. J. Ecol. 2012, 100, 1153-1163. [CrossRef]

61. Van Altena, C.; van Logtestijn, R.; Cornwell, W.; Cornelissen, H. Species composition and fire: Non-additive mixture effects on ground fuel flammability. Front. Plant Sci. 2012, 3, 63.

62. Wyse, S.V.; Perry, G.L.; Curran, T.J. Shoot-level flammability of species mixtures is driven by the most flammable species: Implications for vegetation-fire feedbacks favouring invasive species. Ecosystems 2018, 21, 886-900. [CrossRef] 
63. Dent, J.M.; Buckley, H.L.; Lustig, A.; Curran, T.J. Flame temperatures saturate with increasing dead material in Ulex europaeus, but flame duration, fuel consumption and overall flammability continue to increase. Fire 2019, 2, 6. [CrossRef]

64. Mandle, L.; Bufford, J.L.; Schmidt, I.B.; Daehler, C.C. Woody exotic plant invasions and fire: Reciprocal impacts and consequences for native ecosystems. Biol. Invasions 2011, 13, 1815-1827. [CrossRef]

65. Brooks, M.L.; D'Antonio, C.M.; Richardson, D.M.; Grace, J.B.; Keeley, J.E.; DiTomaso, J.M.; Hobbs, R.J.; Pellant, M.; Pyke, D. Effects of Invasive Alien Plants on Fire Regimes. BioScience 2004, 54, 677. [CrossRef]

66. Jackson, S.T.; Hobbs, R.J. Ecological restoration in the light of ecological history. Science 2009, 325, 567-569. [CrossRef]

67. Robinne, F.-N.; Burns, J.; Kant, P.; Flannigan, M.; Kleine, M.; de Groot, B.; Wotton, D. Global Fire Challenges in a Warming World; Occasional Paper No. 32; International Union of Forest Research Organizations: Vienna, Austria, 2018.

68. Curran, T.; Perry, G.; Wyse, S.; Alam, M. Managing fire and biodiversity in the wildland-urban interface: A role for green firebreaks. Fire 2018, 1, 3. [CrossRef]

69. Cui, X.; Alam, M.A.; Perry, G.L.; Paterson, A.M.; Wyse, S.V.; Curran, T.J. Green firebreaks as a management tool for wildfires: Lessons from China. J. Environ. Manag. 2019, 233, 329-336. [CrossRef]

70. Glogoski, D. Vegetation Recovery Following the 2015 Flock Hill Fire, Canterbury Hign Country. Master's Thesis, University of Canterbury, Christchurch, New Zealand, 2017.

71. Molloy, B.P.J. Apomixis in indigenous New Zealand woody seed plants and its ecological and wider significance: A working hypothesis. N. Z. J. Ecol. 2019, 43, 1-11. [CrossRef]

72. Rogers, G.M.; McGlone, M.S. A history of Kaiparoro clearing and the limits of Nothofagus in the northern Tararua Range, New Zealand. N. Z. J. Bot. 1994, 32, 463-482. [CrossRef]

73. Calder, J.W.; Wardle, P. Succession in subalpine vegetation at Arthur's Pass, New Zealand. N. Z. Ecol. Soc. $1969,16,36-47$.

74. Enright, N.; Cameron, E. The soil seed bank of a kauri (Agathis australis) forest remnant near Auckland, New Zealand. N. Z. J. Bot. 1988, 26, 223-236. [CrossRef]

75. Heginbotham, M.; Esler, A. Wild vascular plants of the Opotiki-East Cape region North Island, New Zealand. N. Z. J. Bot. 1985, 23, 379-406. [CrossRef]

76. Rogers, G.; Leathwick, J. North Island seral tussock grasslands. 3. The influence of heather (Calluna vulgaris) on rates of change from tussock grassland to shrubland. N. Z. J. Bot. 1996, 34, 473-487. [CrossRef]

77. Grubb, P.J.; Bellingham, P.J.; Kohyama, T.S.; Piper, F.I.; Valido, A. Disturbance regimes, gap-demanding trees and seed mass related to tree height in warm temperate rain forests worldwide. Biol. Rev. 2013, 88, 701-744. [CrossRef]

78. Nicholls, J. Vulcanicity and indigenous vegetation in the Rotorua district. N. Z. Ecol. Soc. 1963, 10, 58-65.

79. Wardle, P. Biological flora of New Zealand 6. Metrosideros umbellata Cav.[Syn. M. lucida (Forst. f.) A. Rich.](Myrtaceae) Southern rata. N. Z. J. Bot. 1971, 9, 645-671. [CrossRef]

80. Clarkson, B.D.; Clarkson, B.R. Vegetation decline following recent eruptions on White Island (Whakaari), Bay of Plenty, New Zealand. N. Z. J. Bot. 1994, 32, 21-36. [CrossRef]

81. Ogden, J.; Stewart, G.; Allen, R. Ecology of New Zealand Nothofagus forests. Ecol. Biogeogr. Nothofagus For. 1996, 3, 25-82.

82. Wotton, D.M. Seed germination, dormancy and longevity in the endangered shrub Muehlenbeckia astonii (Polygonaceae). N. Z. J. Bot. 2018, 56, 331-341. [CrossRef]

83. Atkinson, I.A. Successional processes induced by fires on the northern offshore islands of New Zealand. $N$. Z. J. Ecol. 2004, 28, 181-193.

84. Evans, K.B. Resprouting of Coprosma Propinqua and Coprosma Crassifolia after fire at Birdlings Flat, Canterbury; Unpublished Undergraduate Report; University of Lincoln: Lincoln, New Zealand, 2014.

85. Ledgard, N.; Davis, M. Restoration of mountain beech (Nothofagus solandri var. cliffortioides) forest after fire. N. Z. J. Ecol. 2004, 24, 125-135.

(C) 2020 by the authors. Licensee MDPI, Basel, Switzerland. This article is an open access article distributed under the terms and conditions of the Creative Commons Attribution (CC BY) license (http://creativecommons.org/licenses/by/4.0/). 